
AGREEMENT BASED ON LAW NUMBER 13 OF 2003 CONCERNING MANPOWER

\author{
Bunadi dan Marjan Miharja \\ Departement of Law, IBLAM School of Law \\ Jalan Kramat Raya No.25, Jakarta Pusat
}

\begin{abstract}
Industrial relations disputes are common in many companies. The dismissal process is often not in accordance with the provisions of labor regulations, one of which is regarding the dismissal of PKWT / contract workers. The formulation of the problems that the author discusses in this thesis are (1) What is the role of trade unions in fighting for dismissal disputes with PKWT / Contract workers? (2) Is the Application of a Fixed Time Work Agreement (PKWT) in accordance with the provisions of Law Number 13 Year 2003 concerning Manpower?

The research method used in this research is juridical normative, namely looking at the law as a written norm made and promulgated by an authorized official or institution, the nature of descriptive analytical research is a study to obtain an overview of the main object of the problem being researched. The results showed that, the role of trade unions in companies in fighting for dismissal disputes against PKWT / Contract workers in accordance with Law no. 2 of 2004 concerning PPHI article 6 in conjunction with article 8 in conjunction with article 81 , namely by conducting a bipartite effort between the labor union and the company, because the bipartite effort failed, then submitted a mediation request to the Manpower Office. The mediation attempt still failed and subsequently filed a lawsuit for dismissal disputes at the Industrial Relations Court, although it was unsuccessful. The application of a fixed-term employment agreement (PKWT) is contrary to the provisions of Law number 13 of 2003 concerning Manpower Article 59 paragraphs (1), (2), and (7). In addition, the PHI Judge in deciding the case did not reflect a sense of justice and ignored the evidence presented by the plaintiff (the worker).

This problem should not have occurred, if the company obeyed and understood the labor regulations regarding workers who could be promised under a non-permanent contract or PKWTT.
\end{abstract}

Keywords: Labor Union, Work Agreement and PKWT / Contra 


\title{
TINJAUAN YURIDIS PENERAPAN PERJANJIAN KERJA WAKTU TERTENTU BERDASARKAN UNDANG-UNDANG NOMOR 13 TAHUN 2003 TENTANG KETENAGAKERJAAN
}

\author{
Bunadi dan Marjan Miharja \\ Program Studi Sarjana Hukum, Sekolah Tinggi Ilmu Hukum IBLAM \\ Jalan Kramat Raya No.25 Jakarta Pusat
}

\begin{abstract}
Intisari
Perselisihan hubungan industrial sering terjadi dibanyak perusahaan. Proses PHK seringkali tidak sesuai dengan ketentuan peraturan ketenagakerjaan, salah satunya mengenai PHK terhadap pekerja PKWT/Kontrak. Rumusan masalah yang penulis bahas dalam skripsi ini adalah, (1) Bagaimana peranan serikat pekerja dalam memperjuangkan perselisihan PHK terhadap pekerja PKWT/Kontrak ? (2) Apakah Penerapan Perjanjian Kerja Waktu Tertentu (PKWT) sudah sesuai dengan ketentuan Undang-Undang nomor 13 tahun 2003 tentang Ketenagakerjaan ?

Metode penelitian yang digunakan dalam penelitian ini adalah yuridis normatif yaitu memandang hukum sebagai norma tertulis yang dibuat dan diundangkan oleh pejabat atau lembaga yang berwenang, sifat penelitian deskriptif analitis yaitu suatu penelitian untuk memperoleh gambaran tentang obyek pokok masalah yang sedang diteliti. Hasil penelitian menunjukkan bahwa, peranan serikat pekerja diperusahaan dalam memperjuangkan perselisihan PHK terhadap pekerja PKWT/Kontrak sesuai dengan UU No. 2 tahun 2004 tentang PPHI pasal 6 jo pasal 8 jo pasal 81, yaitu dengan melakukan upaya Bipartit antara pihak serikat pekerja dengan perusahaan, karena upaya Bipartit gagal selanjutnya mengajukan permohonan Mediasi ke Dinas Tenaga Kerja. Upaya mediasipun masih gagal selanjutnya mengajukan Gugatan Perselisihan PHK ke Pengadilan Hubungan Industrial meskipun tidak berhasil. Penerapan Perjanjian Kerja Waktu Tertentu (PKWT) bertentangan dengan ketentuan Undang-Undang nomor 13 tahun 2003 tentang Ketenagakerjaan Pasal 59 ayat (1), (2), dan (7). Selain itu Hakim PHI dalam memutus perkara tidak mencerminkan rasa keadilan dan mengabaikan bukti-bukti yang diajukan oleh penggugat (pihak pekerja).

Seharusnya terhadap permasalahan ini tidak perlu terjadi, apabila perusahaan mematuhi dan memahami aturan ketenagakerjaan tentang pekerja yang boleh diperjanjikan secara PKWT atau PKWTT.
\end{abstract}

Kata Kunci : Serikat Pekerja, Perjanjian Kerja dan PKWT/Kontrak 


\section{A. Pendahuluan}

Tujuan indonesia merdeka adalah menciptakan kehidupan bangsa yang sejahtera, adil, makmur dan merata dengan mengisi kegiatan pasca kemerdekaan melalui usaha-usaha peningkatan investasi ekonomi untuk pembangunan nasional. Pembangunan nasional dilaksanakan dalam rangka pembangunan manusia Indonesia seutuhnya dan pembangunan masyarakat Indonesia seluruhnya untuk mewujudkan masyarakat yang sejahtera, adil, makmur, yang merata baik materiil maupun spiritual berdasarkan Pancasila dan Undang-Undang Dasar Negara Republik Indonesia 1945. Tidak dapat dipungkiri dalam pembangunan nasional negara tidak dapat berdiri sendiri untuk melakukan pembangunan karena terbatasnya anggaran dan sumber daya, maka diperlukan juga peran dari swasta dalam pembangunan nasional.

Pada saat ini indonesia termasuk salah satu negara berkembang dengan pertumbuhan ekonomi yang baik, dimana sektor industri sebagai salah satu penyumbang pertumbuhan ekonomi Indonesia. Tumbuhnya ekonomi dari meningkatnya investor terutama asing akan seiring dengan banyaknya lapangan pekerjaan. Dalam proses pelaksanaan pembangunan nasional, tenaga kerja mempunyai peranan dan kedudukan yang penting sebagai pelaku dan tujuan pembangunan. Disamping itu, tenaga kerja juga merupakan modal utama dari pelaksanaan dan pembangunan masyarakat pancasila. Tujuan terpenting dari pembangunan adalah kesejahteraan rakyat termasuk tenaga kerja. Tenaga kerja sebagai pelaksana pembangunan harus di jamin haknya, diatur kewajibannya dan dikembangkan daya gunanya sesuai dengan peranan dan kedudukan tenaga kerja.

Secara normatif, Undang-Undang Dasar 1945 menjamin hak setiap warga negara untuk memperoleh pekerjaan (Pasal 27 Ayat 2). Hal ini dipertegas kembali dalam Undang-Undang Dasar Negara Republik
Indonesia Tahun 1945 (hasil amandemen kedua) Bab XA tentang Hak Asasi Manusia (Pasal 28A-28). Pasal 28D mengamanatkan bahwa "setiap orang berhak untuk bekerja serta mendapat imbalan dan perlakuan yang adil dan layak dalam hubungan kerja".

Asas pembangunan ketenagakerjaan pada dasarnya sesuai dengan asas pembangunan nasional, khususnya asas demokrasi, asas adil dan merata. Pembangunan ketenagakerjaan menyangkut multidimensi dan terkait dengan berbagai pihak, yaitu antara pemerintah, pengusaha dan pekerja atau buruh. Pembangunan ketenagakerjaan dilakukan secara terpadu dalam bentuk kerjasama yang saling mendukung.

Sesuai dengan peranan dan kedudukan tenaga kerja, diperlukan pembangunan ketenagakerjaan untuk meningkatkan kualitas tenaga kerja dan peran sertanya dalam pembangunan serta peningkatan perlindungan tenaga kerja dan keluarganya sesuai dengan harkat dan martabat kemanusiaan. $^{2}$

Untuk itulah diperlukan adanya perlindungan terhadap tenaga kerja dimaksudkan untuk menjamin hak-hak dasar pekerja dan menjamin kesamaan kesempatan serta perlakuan diskriminasi atas dasar apapun untuk mewujudkan kesejahteraan pekerja dan keluarganya dengan tetap memperhatikan perkembangan kemajuan dunia usaha.

Kedudukan pekerja pada hakikatnya dapat ditinjau dari dua segi, yaitu dari segi yuridis dan dari segi sosial ekonomis, dari segi sosial ekonomis, pekerja membutuhkan perlindungan hukum dari negara atas kemungkinan adanya tindakan sewenangwenang dari pengusaha. ${ }^{3}$

Kedudukan antara pengusaha dengan pekerja adalah tidak sama. Secara yuridis

\footnotetext{
${ }^{1}$ Lalu Husni, Pengantar Hukum Ketenagakerjaan Indonesia edisi revisi, (Jakarta: PT. Raja Grafindo Persada, 2015), 13.

2 Abdul Khakim, Pengantar Hukum Ketenagakerjaan Indonesia Berdasarkan Undang-Undang Nomor 13 Tahun 2003, (Bandung: PT. Citra Adytia Bhakti, 2003), 6-7.

3 lbid, 8.
} 
kedudukan buruh adalah bebas, tetapi secara sosial ekonomis, kedudukan buruh adalah tidak bebas. Kedudukan buruh secara yuridis berdasarkan ketentuan Pasal 27 UUD 1945 adalah sama denga majikan. Kenyataannya, secara sosial ekonomi kedudukan antara buruh dengan majikan adalah tidak sama. Kedudukan yang tidak sederajat ini, membuat majikan sering menganggap buruh sebagai objek dalam hubungan kerja. Keadaan ini menimbulkan adanya kecenderungan majikan untuk berbuat sewenang-wenang kepada pekerja/ buruhnya. ${ }^{4}$

Jika hubungan antara buruh dengan majikan ini tetap diserahkan sepenuhnya kepada para pihak (buruh dan majikan), maka tujuan hukum perburuhan untuk menciptakan keadilan sosial dibidang perburuhan akan sangat sulit tercapai, karena pihak yang kuat akan selalu ingin menguasai pihak yang lemah (homo homoni lopus). Majikan sebagai pihak yang kuat secara sosial ekonomi akan selalu menekan pihak buruh yang berada pada posisi yang lemah atau rendah. Atas dasar itulah, pemerintah secara berangsur-angsur turut serta dalam menangani masalah perburuhan melalui berbagai peraturan perundang-undangan. Peraturan perundang-undangan di bidang perburuhan dimaksudkan untuk memberikan kepastian hukum terhadap hak dan kewajiban pengusaha maupun pekerja/buruh. $^{5}$

Tujuan campur tangan pemerintah dalam bidang perburuhan ini untuk mewujudkan perburuhan yang adil, karena peraturan perundang-undangan perburuhan memberikan hak-hak bagi pekerja sebagai manusia yang utuh, karena itu harus dilindungi baik menyangkut keselamatannya, kesehatannya, upah yang layak dan sebagainya. Selain itu pemerintah juga harus memperhatikan kepentingan pengusaha/ majikan yakni kelangsungan perusahaan. ${ }^{6}$

\footnotetext{
${ }^{4}$ Ibid, 9.

Lalu Husni, Op. Cit, 23

${ }^{6}$ lbid, 24.
}

Didalam dunia kerja, setiap orang membutuhkan adanya interaksi atau hubungan dengan orang lain. Baik bagi pemberi kerja ataupun bagi pekerja. Hubungan tersebut dikenal dengan istilah hubungan kerja. Menurut Pasal 1 angka 15 Undang-Undang nomor 13 tahun 2003 tentang Ketenagakerjaan (selanjutnya disingkat menjadi UU Ketenagakerjaan), hubungan kerja ialah hubungan antara pengusaha dan pekerja berdasarkan perjanjian kerja yang mempunyai unsur pekerjaan, upah dan perintah.

Pada pasal 1 angka 15 UU Ketenagakerjaan disebutkan hubungan antara pengusaha dan pekerja adalah berdasarkan perjanjian kerja. Berdasarkan pengertian tersebut, maka untuk dapat dikatakan ada tidaknya suatu hubungan kerja, adalah ada tidaknya perjanjian kerja. ${ }^{7}$ Perjanjian kerja menurut ketentuan Pasal 1 angka 14 UU Ketenagakerjaan, ialah suatu perjanjian antara pekerja/ buruh dan pengusaha atau pemberi kerja yang memuat syarat-syarat kerja hak dan kewajiban kedua belah pihak. Perjanjian kerja berdasarkan ketentuan Pasal 56 UU Ketenagakerjaan dibedakan dalam dua jenis yaitu perjanjian kerja waktu tertentu (selanjutnya disingkat menjadi PKWT) dan perjanjian waktu tidak tertentu (selanjutnya disingkat menjadi PKWTT).

Berkaitan dengan hal tersebut, Pasal 1 angka 3 dan 4 UU Ketenagakerjaan menentukan bahwa pekerja adalah setiap orang yang bekerja dengan menerima upah atau imbalan dalam bentuk lain, sedangkan dalam angka 4 ditentukan bahwa pemberi kerja ialah yang mempekerjakan tenaga kerja dengan membayar upah atau imbalan dalam bentuk lain.

Didalam melaksanakan hubungan kerja antara pengusaha dengan pekerja, pengusaha lebih menyukai sistem kerja kontrak kepada pekerjanya dibandingkan pekerja tetap. Hal ini mudah sekali kita temui di perusahaanperusahaan yang menerapkan dengan sistem kerja tersebut. Cara seperti ini digunakan

${ }^{7}$ Agusmidah, Hukum Ketenagakerjaan Indonesia Dinamika dan Kajian Teori, (Jakarta: Ghalia Indonesia, 2010), 43. 
oleh perusahaan-perusahaan yang mencoba mengakali peraturan dengan memperbarui perjanjian kerja dengan cara berulang-ulang.

Pekerja waktu tertentu merupakan pihak yang dirugikan dalam suatu perjanjian kerja, karena apabila terjadi Pemutusan Hubungan Kerja (PHK) oleh perusahaan, maka pekerja waktu tertentu tidak mendapatkan hak-hak normatif sebagaimana layaknya tenaga kerja tetap, walaupun masa kerja sudah bertahuntahun.

Bahwa perjanjian kerja waktu tertentu hanya dapat dibuat untuk pekerjaan tertentu yang menurut jenis dan sifat atau kegiatan pekerjaannya akan selesai dalam waktu tertentu, dengan artian tidak semua pekerjaan diperusahaan dikerjakan dengan pekerja berdasarkan perjanjian kerja waktu tertentu namun apabila pekerjaannya bersifat tetap atau tidak dibatasi oleh waktu dan pekerjaan tersebut masih tetap ada serta tidak berubahubah, pengusaha tidak boleh melakukan hubungan kerja dengan perjanjian kerja waktu tertentu (PKWT) melainkan harus merubah hubungan kerja pekerja dengan perjanjian kerja waktu tidak tertentu (PKWTT). Praktik seperti ini kerap dilakukan karena beranggapan beban keuangan perusahaan menjadi ringan, jauh lebih murah membayar pekerja berdasarkan dengan perjanjian kerja waktu tertentu (PKWT) dari pada mempekerjakan pekerja dengan status perjanjian kerja waktu tidak tertentu (PKWTT) atau tetap.

Salah satu contoh perkara yang terkait dengan permasalahan Perjanjian Kerja Waktu Tertentu (PKWT) adalah perkara Putusan PN Bandung nomor : 47/Pdt.Sus/PHI/2019/Pn.Bdg. Kronologisnya adalah Muhamad Sulur, Yayan Mulyana, Anggi, Ade Repai dan Tatang Daryanto kesemuanya adalah pekerja PT. Dasa Windu Agung yang melalui kuasanya Serikat Pekerja Gabungan Serikat Pekerja Manufaktur Independen Indonesia (GSPMII) menggugat PT. Dasa Windu Agung karena telah melakukan pemutusan hubungan kerja secara sepihak dengan alasan habis kontrak (PKWT) padahal obyek pekerjaan di PT
Dasa Windu Agung adalah bersifat tetap dan masih berlangsung hingga saat ini. Oleh karena itu pihak pekerja Muhamad Sulur, Yayan Mulyana, Anggi, Ade Repai dan Tatang Daryanto menganggap bahwa status perjanjian kerja waktu tertentu (PKWT) yang diperjanjikan perusahaan PT. Dasa Windu Agung adalah tidak sah karena tidak memenuhi ketentuan dan persyaratan yang ditetapkan oleh peraturan perundangundangan dalam hal ini Undang-Undang nomor 13 tahun 2003 tentang Ketenagakerjaan dan demi hukum berubah menjadi perjanjian kerja waktu tidak tertentu (PKWTT).

Berdasarkan uraian di atas, maka penulis tertarik untuk mengkaji permasalahan tersebut dengan judul "Tinjauan Yuridis Penerapan Perjanjian Kerja Waktu Tertentu (PKWT) PT. Dasa Windu Agung Berdasarkan Undang-Undang Nomor 13 Tahun 2003 Tentang Ketenagakerjaan (Studi Kasus Putusan PN. Bandung Nomor : 47/Pdt.Sus-PHI/2019/PN.Bdg).

Berdasarkan latar belakang permasalahan diatas, maka yang dapat dijadikan sebagai rumusan masalah adalah:

1. Bagaimana Peranan Serikat Pekerja diperusahaan PT. Dasa Windu Agung dalam memperjuangkan Perselisihan PHK terhadap pekerja PKWT/Kontrak?

2. Apakah Penerapan Perjanjian Kerja Waktu Tertentu (PKWT) di PT. Dasa Windu Agung sudah sesuai dengan ketentuan Undang-Undang nomor 13 tahun 2003 tentang Ketenagakerjaan?

Adapun tujuan yang ingin dicapai penulis dalam penelitian ini adalah :

1. Untuk mengetahui bagaimana peranan serikat pekerja diperusahaan PT. Dasa Windu Agung dalam memperjuangkan perselisihan PHK terhadap pekerja PKWT/Kontrak.

2. Untuk mengetahui apakah penerapan perjanjian kerja waktu tertentu (PKWT) di PT. Dasa Windu Agung sudah sesuai dengan ketentuan 
Undang-Undang nomor 13 tahun 2003 tentang Ketenagakerjaan.

3. Sedangkan kegunaan atau manfaat dari penelitian ini adalah, bahwa bagi penulis diharapkan dapat memberikan dan mengembangkan wawasan penulis dalam memahami peranan serikat pekerja dalam memperjuangkan pekerja perjanjian kerja waktu tertentu (PKWT) di PT. Dasa Windu Agung dan untuk mengetahui apakah penerapan perjanjian kerja waktu tertentu (PKWT) di PT. Dasa Windu Agung sudah sesuai dengan ketentuan Undang-Undang nomor 13 tahun 2003 tentang Ketenagakerjaan.

Penelitian Hukum adalah suatu penelitian yang mempunyai objek hukum, baik hukum sebagai suatu ilmu atau aturanaturan yang sifatnya dogmatis maupun hukum yang berkaitan dengan perilaku dan kehidupan masyarakat. Penelitian hukum pada dasarnya merupakan suatu kegiatan ilmiah, yang didasarkan pada metode, sistematika dan pemikiran tertentu, yang bertujuan untuk mempelajari satu atau beberapa gejala hukum tertentu dengan jalan menganalisanya. Kecuali itu, maka juga diadakan pemeriksaan yang mendalam terhadap fakta hukum tersebut, untuk kemudian mengusahakan suatu pemecahan atas permasalahan-permasalahan yang timbul di dalam gejala bersangkutan. ${ }^{8}$

\section{B. Metode Penelitian}

Sajian metode penelitian ini disistematisasikan dalam suatu format sebagai berikut:

1. Metode Pendekatan Untuk menjawab permasalahan dan mencapai tujuan dari penelitian ini, peneliti menggunakan model pendekatan normatif. Penelitian hukum normatif adalah penelitian hukum yang dilakukan dengan cara meneliti bahan pustaka atau data sekunder belaka. ${ }^{9}$

\footnotetext{
8 Jonaedi Efendi dan Johny Ibrahim, Metode Penelitian Hukum Normatif dan Empiris, (Depok: Prenadamedia Group, 2018), 16.

Soerjono Soekanto, Sri Mamudji, Penelitian Hukum Normatif, (Jakarta: Raja Grafindo, 2013), 13-14.
}

2. Sifat Penelitian Tipe penelitian ini menurut sifatnya adalah tipe penelitian deskriptif, yaitu bertujuan menggambarkan secara tepat sifat-sifat suatu individu, keadaan, gejala atau kelompok tertentu, atau untuk menentukan penyebaran suatu gejala, atau untuk menentukan ada tidaknya hubungan antara suatu gejala dengan gejala lain dalam masyarakat. ${ }^{10}$

3. Jenis Data dan Teknik Pengumpulan Data Data yang digunakan adalah data sekunder, adapun yang dimaksud dengan data sekunder adalah data yang diperoleh dari bahan-bahan pustaka yang terdiri dari tiga bahan hukum, yaitu :

a. Bahan hukum Primer, yaitu peraturan perundang-undangan yang terkait, antara lain, Undang-Undang Nomor 13 Tahun 2003 Tentang Ketenagakerjaan, Undang-Undang Nomor 21 Tahun 2000 Tentang Serikat Pekerja/Serikat Buruh, Undang-Undang Nomor 2 Tahun 2004 Tentang Penyelesaian Perselisihan Hubungan Industrial, Peraturan Pemerintah, KeputusanKeputusan Mahkamah Agung, Peraturan Menteri Tenaga Kerja dan peraturan-peraturan lainnya yang berkaitan dengan judul skripsi.

b. Bahan hukum sekunder, yaitu bahan yang memberikan penjelasan mengenai bahan hukum primer yang terdiri dari buku-buku, jurnal, artikel-artikel, berita-berita dan sebagainya yang diperoleh baik dari media cetak maupun media elektronik yang berkaitan dengan materi penelitian yang dapat memperkaya referensi dalam penyelesaian penelitian ini.

c. Bahan hukum tersier, yang terdiri dari kamus hukum, Kamus Besar Bahasa Indonesia yang dapat memberikan penjelasan maupun

${ }^{10}$ Amirudin dan Zainal Asikin, Pengantar Metode Penelitian Hukum, (Jakarta: Rajawali Pers, 2010), 25. 
petunjuk terhadap bahan hukum primer maupun bahan hukum sekunder. Adapun pungumpulan data dalam penelitian ini adalah dengan melakukan penelitian kepustakaan yaitu dengan melakukan pengumpulan data-data yang kemudian menelaah, mengkaji, dan menganalisis bahanbahan literatur hukum serta dokumen-dokumen tulisan ilmiah yang berupa peraturan perundangundangan, buku-buku Ilmiah, serta yang berhubungan dengan permasalahan yang penulis teliti yaitu Putusan PN Bandung Nomor : 47/Pdt.Sus-PHI/2019/PN.Bdg.

Tujuan utama seseorang bekerja pada sebuah perusahaan adalah untuk memperoleh upah. Sehingga jika tidak ada unsur upah, maka suatu hubungan tersebut bukan merupakan hubungan kerja. Hubungan kerja adalah hubungan-hubungan dalam rangka pelaksanaan kerja antara para pekerja dengan pengusaha dalam suatu perusahaan yang berlangsung dalam batas-batas perjanjian kerja dan peraturan kerja yang telah disepakati bersama oleh pekerja dan pengusaha. Dengan terwujudnya hubungan kerja, maka baik pengusaha maupun pekerja yang bersangkutan masing-masing telah terikat oleh isi perjanjian tersebut dan masing-masing telah memperoleh hak, dimana pengusaha berhak memerintah dan menugaskan pekerja agar bekerja dengan giat dan rajin tanpa melampaui batas-batas isi perjanjian kerja, dan pekerja berhak menerima upah dan jaminan-jaminan lainnya yang diberikan pengusaha tanpa melampaui pula batas-batas isi perjanjian kerja. ${ }^{11}$

Hubungan kerja adalah hubungan antara pekerja dengan pengusaha yang terjadi setelah adanya perjanjian kerja, yakni suatu perjanjian dimana pekerja menyatakan kesanggupan untuk bekerja pada pihak perusahaan/ majikan dengan menerima upah dan majikan/ pengusaha menyatakan

\footnotetext{
${ }^{11}$ G. Kartasapoetra, dkk, Hukum Perburuhan di Indonesia
} Berlandaskan Pancasila, (Jakarta: Sinar Grafika, 1994), 18. kesanggupannya untuk mempekerjakan pekerja dengan membayar upah. ${ }^{12}$

Pengertian hubungan kerja menurut Pasal 1 angka 15 Undang-undang Nomor 13 Tahun 2003 tentang Ketenagakerjaan disebutkan bahwa hubungan kerja adalah hubungan antara pengusaha dengan pekerja/buruh berdasarkan perjanjian kerja yang mempunyai unsur pekerjaan, upah, dan perintah.

Selain pengertian hubungan kerja diatas, ada juga pengertian hubungan kerja menurut pakar diantaranya :

1. Menurut Hartono dan Judiantoro, pengertian hubungan kerja adalah kegiatan-kegiatan pengerahan tenaga kerja/ jasa seseorang secara teratur demi kepentinngan orang lain yang memerintahnya (pengusaha/majikan) sesuai dengan perjanjian kerja yang telah disepakati.

2. Menurut Tjepi F. Aloewie, hubungan kerja adalah hubungan yang terjalin antara pengusaha dan pekerja yang timbul dari perjanjian yang diadakan untuk jangka waktu tertentu maupun tidak tertentu. ${ }^{14}$

3. Menurut Iman Soepomo, hubungan kerja adalah hubungan antara pekerja dan pengusaha, yang terjadi setelah diadakan perjanjian kerja oleh pekerja dengan pengusaha, dimana pekerja menyatakan kesanggupannya untuk bekerja pada pengusaha dengan menerima upah dan dimana pengusaha menyatakan kesanggupannya untuk memperkerjakan pekerja dengan membayar upah. ${ }^{15}$

\footnotetext{
${ }^{12}$ Lalu Husni, Op. Cit, 113.

Hartono, Judiantoro, Segi Hukum Penyelesaian Perselisihan Perburuhan, (Jakarta: Rajawali Pers, 1992), 10.

${ }^{14}$ Tjepi F. Aloewie, Naskah Akademis Tentang Pemutusan Hubungan Kerja dan Penyelesaian Perselisihan Industrial, (Jakarta: BPHN, 1996), 32.

${ }^{15}$ Djumadi, Hukum Perburuhan Perjanjian Kerja, (Jakarta, Rajawali Pers, 2002), 36
} 
Berdasarkan pengertian mengenai hubungan kerja, terdapat tiga unsur pokok yaitu: ${ }^{16}$

a. Adanya unsur pekerjaan

Secara teknis jelas tidak mungkin pengusaha akan merekrut pekerja/ buruh jika tidak tersedia pekerjaan sesuai dengan kapasitas perusahaannya. Secara yuridis unsur ini merupakan salah satu syarat sahnya perjanjian kerja, sebagaimana diatur dalam Pasal 52 ayat (1) Undang-Undang Nomor 13 Tahun 2003 yang mengadopsi Pasal 1320 KUH Perdata. Dimana unsur adanya pekerjaan sebagai syarat objektif dari perjanjian kerja sehingga objek perjanjian kerja harus jelas. Jika syarat objektif tidak terpenuhi, perjanjian kerja batal demi hukum.

b. Adanya unsur perintah

Disinilah letak strategisnya pengusaha dan ia memiliki bargaining position cukup kuat dibanding pekerja/ buruh. Dengan demikian, pengusaha berhak biasanya dalam peraturan perusahaan atau perjanjian kerja bersama disebut "hak prerogratif pengusaha" melakukan perintah kepada pekerja/ buruh sesuai kebutuhan operasional perusahaannya sehingga pekerja/ buruh mengikatkan diri pada pengusaha untuk bekerja dibawah perintah pengusaha. Menurut istilah para ahli hukum hal ini disebut sebagai hubungan diperatas (dienstverhoeding), artinya pekerja/ buruh harus bersedia bekerja dibawah perintah orang lain.

c. Adanya unsur upah

Tidak mungkin seorang pekerja/ buruh mau bekerja jika tanpa adanya upah yang sesuai dengan kebutuhannya. Upah dalam ketentuan ketenagakerjaan minimal adalah Upah Minimum Provinsi (UMP) atau Upah Minimum

\footnotetext{
${ }^{16}$ Abdul Khakim, Dasar-Dasar Hukum Ketenagakerjaan Indonesia Cetakan ke-4 Edisi Revisi, (Bandung: PT. Citra Aditya Bakti, 2014), 40.
}

Sektoral Provinsi (UMSP) yang ditetapkan oleh Gubernur.

Pada dasarnya hubungan kerja merupakan hubungan yang mengatur atau memuat hak dan kewajiban antara pekerja/ buruh dan pengusaha. Takaran hak dan kewajiban masing-masing pihak haruslah seimbang. Dalam konteks hubungan kerja, kewajiban para pihak berlangsung secara timbal balik. Artinya, "kewajiban pengusaha merupakan hak pekerja/ buruh" dan sebaliknya "kewajiban pekerja/buruh merupakan hak pengusaha". Untuk itu, jika terjadi pelanggaran kewajiban yang telah diatur peraturan perundang-undangan atau perjaniian kerja, masing-masing pihak dapat menuntut pihak lainnya. ${ }^{17}$

\section{Perjanjian Kerja}

Perjanjian kerja berdasarkan Pasal 1601 a KUHPerdata memberikan pengertian sebagai berikut: "Perjanjian kerja adalah suatu perjanjian dimana pihak kesatu (si buruh), mengikatkan dirinya untuk dibawah perintah pihak yang lain, si majikan untuk suatu waktu tertentu melakukan pekerjaan dengan menerima upah."

Undang-undang Nomor 13 Tahun 2003 tentang Ketenagakerjaan, Pasal 1 angka 14 memberikan pengertian bahwa perjanjian kerja adalah suatu perjanjian antara pekerja/buruh dan pengusaha atau pemberi kerja yang memuat syarat-syarat kerja, hak dan kewajiban kedua belah pihak.

Imam Soepomo berpendapat bahwa perjanjian kerja adalah suatu perjanjian dimana pihak kesatu (buruh), mengikatkan diri untuk bekerja dengan menerima upah dari pihak kedua yakni majikan, dan majikan mengikatkan diri untuk mempekerjakan buruh dengan membayar upah. ${ }^{18}$

Perjanjian kerja harus memenuhi syarat sahnya perjanjian sebagaimana diatur dalam Pasal 1320 KUHPerdata. Ketentuan ini juga tertuang dalam Pasal 52 ayat (1) Undangundang No. 13 Tahun 2003 tentang

\footnotetext{
${ }^{17} \mathrm{Ibid}, 42$.

${ }^{18}$ Imam Soepomo, Pengantar Hukum Perburuhan, (Jakarta: djambatan 1985), 53.
} 
Ketenagakerjaan yang menyebutkan bahwa perjanjian kerja dibuat atas dasar:

a. Kesepakatan kedua belah pihak;

b. Kemampuan atau kecakapan melakukan perbuatan hukum;

c. Adanya pekerjaan yang diperjanjikan;

d. Pekerjaan yang diperjanjikan tidak boleh bertentangan dengan ketertiban umum, kesusilaan, dan ketentuan peraturan perundang-undangan yang berlaku.

Dasar huruf a dan b merupakan syarat subjektif, sedangkan dasar huruf $\mathrm{c}$ dan $\mathrm{d}$ merupakan syarat objektif. Dalam hal terjadi dimana perjanjian kerja itu tidak memenuhi syarat subjektif, maka perjanjian itu dapat dibatalkan. Artinya, salah satu pihak (yang tidak cakap) memiliki hak untuk meminta agar perjanjian kerja itu dibatalkan oleh hakim. Kemudian, apabila perjanjian kerja itu tidak memenuhi syarat objektif, perjanjian itu batal demi hukum. Artinya, dari semula dianggap tidak pernah ada perjanjian atau perikatan sehingga para pihak tidak memiliki dasar untuk saling menuntut dimuka sidang pengadilan. ${ }^{19}$

Dalam perjanjian kerja adanya hak dan kewajiban pekerja dan pengusaha, yaitu:

a. Hak pekerja, diantaranya:

1) Pekerja berhak atas upah setelah melaksanakan kewajibannya sesuai dengan perjanjian

2) Hak atas fasilitas-fasilitas lain berupa tunjangan, dana bantuan, dan lain-lain

b. Hak pengusaha, diantaranya:

1) Pengusaha berhak sepenuhnya atas hasil kerja pekerja, artinya seluruh hasil pekerjaan pekerja adalah menjadi milik pengusaha

2) Pengusaha berhak atas ditaatinya aturan kerja yang diberikan kepada pekerja

c. Kewajiban pekerja, diantaranya:

1) Melaksanakan tugas dengan baik sesuai dengan perjanjian dan kemampuannya

\footnotetext{
${ }^{19}$ Abdul Khakim, Op. Cit, 50.
}

2) Patuh dan taat atas segala perintah pengusaha dalam melaksanakan pekerjaan sesuai dengan perjanjian

d. Kewajiban pengusaha, diantaranya:

1) Pengusaha berkewajiban membayar imbalan kepada pekerja berupa upah atau gaji sesuai dengan jumlah dan waktu yang telah ditentukan

2) Pengusaha berkewajiban menyediakan dan mengatur fasilitas kerja, tempat kerja dan alat kerja

\section{Perjanjian Kerja Waktu Tertentu}

Perjanjian kerja waktu tertentu yang selanjutnya disebut PKWT adalah perjanjian kerja antara pekerja/buruh dengan pengusaha untuk mengadakan hubungan kerja dalam waktu tertentu atau untuk pekerja tertentu ${ }^{20}$, Perjanjian kerja waktu tertentu pula diatur mulai pada pasal 56 sampai dengan pasal 59 Undang-Undang No. 13 tahun 2003 tentang ketenagakerjaan yang berbunyi :

\section{Pasal 56}

Perjanjian kerja dibuat untuk waktu tertentu atau untuk waktu tidak tertentu.

(2) Perjanjian kerja untuk waktu tertentu sebagaimana dimaksud dalam ayat (1) didasarkan atas:

a. jangka waktu; atau

b. selesainya suatu pekerjaan tertentu.

\section{Pasal 57}

(1) Perjanjian kerja untuk waktu tertentu dibuat secara tertulis serta harus menggunakan bahasa Indonesia dan huruf latin.

(2) Perjanjian kerja untuk waktu tertentu yang dibuat tidak tertulis bertentangan dengan ketentuan sebagaimana dimaksud dalam ayat (1) dinyatakan sebagai perjanjian kerja untuk waktu tidak tertentu.

(3) Dalam hal perjanjian kerja dibuat dalam bahasa Indonesia dan bahasa asing, apabila kemudian terdapat perbedaan penafsiran antara keduanya,

${ }^{20}$ Keputusan Menteri Tenaga Kerja Nomor 100 Tahun 2004 Tentang Pelaksanaan Perjanjian Kerja Waktu Tertentu, Pasal 1 angka 1. 
maka yang berlaku perjanjian kerja yang dibuat dalam bahasa Indonesia.

\section{Pasal 58}

(1) Perjanjian kerja untuk waktu tertentu tidak dapat mensyaratkan adanya masa percobaan kerja.

(2) Dalam hal disyaratkan masa percobaan kerja dalam perjanjian kerja sebagaimana dimaksud dalam ayat (1), masa percobaan kerja yang disyaratkan batal demi hukum

\section{Pasal 59}

(1) Perjanjian kerja untuk waktu tertentu hanya dapat dibuat untuk pekerjaan tertentu yang menurut jenis dan sifat atau kegiatan pekerjaannya akan selesai dalam waktu tertentu, yaitu:

a. pekerjaan yang sekali selesai atau yang sementara sifatnya;

b. pekerjaan yang diperkirakan penyelesaiannya dalam waktu yang tidak terlalu lama dan paling lama 3 (tiga) tahun;

c. pekerjaan yang bersifat musiman; atau

d. pekerjaan yang berhubungan dengan produk baru, kegiatan baru, atau produk tambahan yang masih dalam percobaan atau penjajakan.

(2) Perjanjian kerja untuk waktu tertentu tidak dapat diadakan untuk pekerjaan yang bersifat tetap.

(3) Perjanjian kerja untuk waktu tertentu dapat diperpanjang atau diperbaharui.

(4) Perjanjian kerja waktu tertentu yang didasarkan atas jangka waktu tertentu dapat diadakan untuk paling lama 2 (dua) tahun dan hanya boleh diperpanjang 1 (satu) kali untuk jangka waktu paling lama 1 (satu) tahun.

(5) Pengusaha yang bermaksud memperpanjang perjanjian kerja waktu tertentu tersebut, paling lama 7 (tujuh) hari sebelum perjanjian kerja waktu tertentu berakhir telah memberitahukan maksudnya secara tertulis kepada pekerja/buruh yang bersangkutan.

(6) Pembaruan perjanjian kerja waktu tertentu hanya dapat diadakan setelah melebihi masa tenggang waktu 30 (tiga puluh) hari berakhirnya perjanjian kerja waktu tertentu yang lama, pembaruan perjanjian kerja waktu tertentu ini hanya boleh dilakukan 1 (satu) kali dan paling lama 2 (dua) tahun.

(7) Perjanjian kerja untuk waktu tertentu yang tidak memenuhi ketentuan sebagaimana dimaksud dalam ayat (1), ayat (2), ayat (4), ayat (5), dan ayat (6) maka demi hukum menjadi perjanjian kerja waktu tidak tertentu.

(8) Hal-hal lain yang belum diatur dalam Pasal ini akan diatur lebih lanjut dengan Keputusan Menteri ${ }^{21}$.

Mengenai keputusan menteri yang mengatur tentang Perjanjian Kerja Waktu Tertentu ada beberapa jenis tentang perjanjian kerja waktu tertentu yaitu :

\section{PKWT UNTUK PEKERJAAN YANG} SEKALI SELESAI

ATAU SEMENTARA SIFATNYA YANG PENYELESAIANNYA

PALING LAMA 3 (TIGA) TAHUN

\section{Pasal 3}

(1) PKWT untuk pekerjaan yang sekali selesai atau sementara sifatnya adalah PKWT yang didasarkan atas selesainya pekerjaan tertentu.

(2) PKWT sebagaimana dimaksud dalam ayat (1) dibuat untuk paling lama 3 (tiga) tahun.

(3) Dalam hal pekerjaan tertentu yang diperjanjikan dalam PKWT sebagaimana dimaksud dalam ayat (1) dapat diselesaikan lebih cepat dari yang diperjanjikan maka PKWT tersebut putus demi hukum pada saaat selesainya pekerjaan.

(4) Dalam PKWT yang didasarkan atas selesainya pekerjaan tertentu harus dicantumkan batasan suatu pekerjaan dinyatakan selesai.

(5) Dalam hal PKWT dibuat berdasarkan selesainya pekerjaan tertentu namun karena kondisi tertentu pekerjaan

${ }^{21}$ UU No. 13 tahun 2003 Tentang Ketenagakerjaan Pasal 59 ayat (1),(2),(3),(4),(5),(6),(7), dan (8). 
tersebut belum dapat diselesaikan, dapat dilakukan pembaharuan PKWT.

(6) Pembaharuan sebagaimana dimaksud dalam ayat (5) dilakukan setelah melebihi masa tenggang waktu 30 (tiga puluh) hari setelah berakhirnya perjanjian kerja.

(7) Selama tenggang waktu 30 (tiga puluh) hari sebagaimana dimaksud dalam ayat (6) tidak ada hubungan kerja antara pekerja/buruh dan pengusaha.

(8) Para pihak dapat mengatur lain dari ketentuan dalam ayat (5) dan ayat (6) yang dituangkan dalam perjanjian.

\section{PKWT UNTUK PEKERJAAN YANG BERSIFAT MUSIMAN}

\section{Pasal 4}

(1) Pekerjaan yang bersifat musiman adalah pekerjaan yang pelaksanaannya tergantung pada musim atau cuaca.

(2) PKWT yang dilakukan untuk pekerjaan sebagaimana dimaksud dalam ayat (1) hanya dapat dilakukan untuk satu jenis pekerjaan pada musim tertentu.

\section{Pasal 5}

(1) Pekerjaan-pekerjaan yang harus dilakukan untuk memenuhi pesanan atau target tertentu dapat dilakukan dengan PKWT sebagai pekerjaan musiman.

(2) PKWT yang dilakukan untuk pekerjaan sebagaimana dimaksud dalam ayat (1) hanya diberlakukan untuk pekerja/buruh yang melakukan pekerjaan tambahan.

\section{Pasal 6}

Pengusaha yang mempekerjaan pekerja/buruh berdasarkan PKWT sebagaimana dimaksud dalam Pasal 5 harus membuat daftar

nama pekerja/buruh yang melakukan pekerjaan tambahan.

\section{Pasal 7}

PKWT sebagaimana dimaksud dalam Pasal 4 dan Pasal 5 tidak dapat dilakukan pembaharuan.

\section{PKWT UNTUK PEKERJAAN YANG BERHUBUNGAN DENGAN PRODUK BARU Pasal 8}

(1) PKWT dapat dilakukan dengan pekerja/buruh untuk melakukan pekerjaan yang berhubungan dengan produk baru, kegiatan baru, atau produk tambahan yang masih dalam percobaan atau penjajakan.

(2) PKWT sebagaimana dimaksud dalam ayat (1) hanya dapat dilakukan untuk jangka waktu paling lama 2 (dua) tahun dan dapat diperpanjang untuk satu kali paling lama 1 (satu) tahun.

(3) PKWT sebagaimana dimaksud dalam ayat (1) tidak dapat dilakukan pembaharuan.

\section{Pasal 9}

PKWT sebagaimana dimaksud dalam Pasal 8 hanya boleh diberlakukan bagi pekerja/buruh yang melakukan pekerjaan di luar kegiatan atau di luar pekerjaan yang biasa dilakukan perusahaan.

\section{Perjanjian Kerja Waktu Tidak Tertentu}

Menurut pasal 50 undang-undang No. 13 tahun 2003 tentang ketenagakerjaan suatu hubungan kerja terjadi karena adanya perjanjian kerja antara pengusaha dengan pekerja/buruh.Segala biaya yang perlu dikeluarkan dalam rangka pembuatan dan pelaksanaan perjanjian kerja menjadi tanggung jawab pengusaha. Adapun jenis perjanjian kerja ada 2 (dua) macam yakni, perjanjian kerja waktu tertentu (PKWT) dan perjanjian kerja waktu tidak tertentu (PKWTT).

Perjanjian Kerja Waktu Tidak Tertentu (PKWTT) adalah perjanjian kerja antara pekerja atau buruh dengan pengusaha untuk mengadakan hubungan kerja yang bersifat tetap. Pada PKWTT ini dapat disyaratkan adanya masa percobaan (maksimal 3 bulan). Pekerja atau buruh yang dipekerjakan dalam 
masa percobaan upahnya harus minimal sesuai dengan upah minimum yang berlaku. ${ }^{22}$ Selain tertulis, PKWTT juga dapat dibuat secara lisan berdasarkan undangundang ketenagakerjaan. Jika PKWTT dibuat secara lisan maka hubungan kerja yang mengatur (pengusaha dan buruh) adalah undang-undang ketenagakerjaan, pengusaha dan buruh dianggap menyetujui seluruh isi undang-undang ketenagakerjaan sebagai sumber hubungan hukum kerja mereka jika PKWTT dibuat secara lisan maka pengusaha wajib membuat surat pengangkatan bagi pekerja yang bersangkutan.

Namun penerapan PKWTT teramat sulit disebuah perusahaan walaupun secara aturan perundang-undangan sudah jelas bahwa apabila terjadi pelanggaran atau penyimpangan terhadap perjanjian kerja yang dibuat oleh perusahaan maka resiko yang timbul adalah perubahan status hubungan kerja dari PKWT menjadi PKWTT baik itu dengan sendirinya maupun dilakukan lewat perundingan oleh serikat pekerja.

\section{Perubahan status hubungan kerja dari Perjanjian Kerja Waktu Tertentu (PKWT) menjadi Perjanjian Kerja Waktu Tidak Tertentu (PKWTT).}

Perubahan perjanjian kerja waktu tertentu menjadi perjanjian kerja waktu tidak tertentu, berdasarkan pasakl 15 Kemenaker Nomor 100 tahun 2004, ada 4 (empat) penyebab perubahan PKWT menjadi PKWTT yaitu :

1. PKWT yang dibuat tidak tertulis dan tidak dalam bahasa indonsia dan huruf latin berubah menjadi PKWTT sejak adanya hubungan kerja.

2. Dalam PKWT dibuat tidak memenuhi ketentuan sebagaimana dimaksud dalam pasal 4 ayat (2) yakni : PKWT

22 Marjan Miharja,"Ketenagakerjaan Dalam Institusi Organisasi Masyarakat (Ormas) Muhammadiyah Kramatjati", Jurnal Anadara Pengabdian Kepada Masyarakat. 2020, Vol.2 No.1. yang dilakukan untuk pekerjaan yang bersifat musiman hanya dapat dilakukan untuk satu jenis pekerjaan pada musim tertentu atau pasal 5 ayat (2) dimana PKWT yang dilakukan untuk pekerjaan-pekerjaan yang harus dilakukan untuk memenuhi pesanan hanya diberlakukan untuk pekerja/buruh yang melakukan pekerjaan tambahan, maka PKWT berubah menjadi PKWTT sejak adanya hubungan kerja.

3. Dalam hal PKWT dilakukan untuk pekerjaan yang berhubungan dengan produk baru menyimpang dari ketentuan pasal 8 ayat (2) dimana PKWT untuk melakukan pekerjaan yang berhubungan dengan produk baru, kegiatan baru atau produk tambahan yang masih dalam percobaan hanya dapat dilakukan untuk jangka waktu paling lama 2 tahun dan dapat diperpanjang 1 kali paling lama 1 tahun serta pada ayat 3 dimana PKWT untuk pekerjaan tersebut tidak dapat dilakukan pembaharuan, maka PKWT berubah menjadi PKWTT sejak dilakukan penyimpangan.

4. Dalam hal pembaharuan PKWT tidak melalui masa tenggang waktu 30 hari setelah berakhirnya perpanjangan PKWT dan diperjanjikan lain sebagaimana dimaksudkan pasal 3 ayat (6) dan (7) dimana pembaharuan PKWT dilakukan setelah melebihi masa tenggang waktu 30 (tiga puluh) hari setelah berakhirnya perjanjian kerja dan selama tenggang waktu tersebut tidak ada hubungan kerja antara pekerja/buruh dengan pengusaha maka PKWT berubah menjadi PKWTT sejak tidak dipenuhinya syarat PKWT tersebut ${ }^{23}$.

Perubahan hubungan kerja dari perjanjian kerja waktu tertentu (PKWT) menjadi perjanjian kerja waktu tidaktertentu (PKWTT), tersebut sudah teramat jelas

${ }^{23} \mathrm{lbid}$. 
diatur didalam Keputusan Menteri Nomor 100 tahun 2004 dimana perubahan hubungan kerja tersebut mencerminkan nilai-nilai keadilan bagi pekerja dan merupakan perlindungan bagi pekerja PKWT. Bahwa salah satu peranan serikat pekerja menyelesaikan masalah tentang kejelasan status hubungan kerja antara pekerja dengan pengusaha sehingga memenuhi rasa keadilan bagi pekerja PKWT.

\section{Perselisihan Hubungan Industrial}

Manusia adalah makhluk sosial (zoon politicon), yakni makhluk yang tidak dapat melepaskan diri dari berhubungan dengan orang lain dalam rangka memenuhi kebutuhan hidupnya sehari-hari. Dalam melakukan hubungan tersebut adakalanya berjalan baik-baik saja, tidak terjadi masalah, tercapai suatu persamaan dalam hubungan tersebut, tetapi adakalanya juga dapat saja terjadi suatu perbedaan, pertentanganpertentangan yang pada akhirnya menimbulkan Perselisihan atau konflik dalam hubungan tersebut. ${ }^{24}$

Begitu pula di dalam hubungan industrial, yakni hubungan antara pekerja/buruh dan pengusaha adakalanya juga bisa terjadi pertentangan-pertentangan, perbedaan-perbedaan atau konflik, sehingga menimbulkan apa yang dinamakan Perselisihan Hubungan Industrial. ${ }^{25}$

Pengertian Perselisihan Hubungan Industrial berdasarkan ketentuan Pasal 1 angka 1, Undang-undang No. 2 Tahun 2004 tentang Penyelesaian Perselisihan Hubungan Industrial adalah "perbedaan pendapat yang mengakibatkan pertentangan antara pengusaha atau gabungan pengusaha dengan pekerja/buruh atau serikat pekerja/serikat buruh karena adanya Perselisihan mengenai hak, Perselisihan kepentingan, Perselisihan pemutusan hubungan kerja, dan Perselisihan antar serikat pekerja/serikat buruh dalam satu perusahaan".

\footnotetext{
${ }^{24}$ Ugo \& Pujiyo, Hukum Acara Penyelesaian Perselisihan Hubungan Industrial, (Jakarta: Sinar Grafika, 2012), 15. ${ }^{25}$ Ibid, 24.
}

Menurut Supomo Suparman mengutip pendat Dr. Payaman J. Simanjuntak mengatakan bahwa, definisi hubungan industrial adalah hubungan antara semua pihak yang terkait atau berhak atas proses produksi barang atau pelayanan jasa di suatu perusahaan. $^{26}$

Menurut Ugo \& Pujio mengutip pendapat Muzni Tambuzai, menyatakan bahwa hubungan industrial pada intinya merupakan pola hubungan interaktif yang terbentuk diantara para pelaku proses produksi barang dan jasa (pengusaha, pekerja/buruh, dan pemerintah) dalam suatu hubungan kerja. ${ }^{27}$

Sehingga dapat dikatakan bahwa hubungan industrial adalah hubungan antara pengusaha dan pekerja dalam perusahaan, serta peran serta pemerintah sebagai yang menetapkan peraturan perundang-undangan ketenagakerjaan.

Dalam melaksanakan hubungan industrial, pengusaha dan organisasi pengusahanya mempunyai fungsi menciptakan kemitraan, mengembangkan usaha, memperluas lapangan kerja, dan memberikan kesejahteraan pekerja/buruh secara terbuka, demokratis, dan berkeadilan.

Begitu juga dengan pekerja/buruh dan serikat pekerja/serikat buruhnya dalam melaksanakan hubungan industrial mempunyai fungsi menjalankan pekerjaan sesuai dengan kewajibannya, menjaga ketertiban demi kelangsungan produksi, menyalurkan aspirasi secara demokratis, mengembangkan keterampilan dan keahliannya serta ikut memajukan perusahaan dan memperjuangkan kesejahteraan anggota beserta keluarganya.

Dengan adanya hubungan industrial tersebut, maka terjadilah hubungan hukum khususnya antara pengusaha dan pekerja untuk menciptakan hubungan yang harmonis.Hubungan hukum tersebut menimbulkan hak dan kewajiban masing-

${ }^{26}$ Supomo Suparman, Hukum Acara Peradilan Hubungan Industrial, Tata cara penyelesaian Sengketa Perburuhan, (Jakarta: Jala Aksara Permata, 2009), 3.

${ }^{27}$ Ugo \& Pujiyo, Op. Cit, 12. 
masing pihak, yang mana hak dan kewajiban tersebut diatur di dalam peraturan perundang-undangan (salah satunya UU No. 13 Tahun 2003) serta dengan adanya perjanjian kerja, peraturan perusahaan juga Perjanjian Kerja Bersama.

Hak dan kewajiban yang sudah ditentukan tersebut kadangkala dilanggar oleh salah satu pihak, maka timbulah Perselisihan atau persengketaan, yang mana Perselisihan ini disebut Perselisihan Hubungan Industrial. Pihak yang merasa haknya dilanggar dapat menuntut hak tersebut, yang mana dalam menuntut hak tersebut diperlukan tata cara sesuai dengan aturan-aturan yang berlaku. Tata cara inilah yang disebut dengan hukum acara. ${ }^{28}$

Berdasarkan Undang-undang Nomor 2 Tahun 2004 tentang Penyelesaian Perselisihan Hubungan Industrial menyebutkan tata cara Penyelesaian Perselisihan Hubungan Industrial di luar pengadilan sebagai berikut:

\section{Penyelesaian Melalui Bipartit}

Lazimnya perundingan bipartit identik dengan penyelesaian sengketa di luar pengadilan (nonlitigasi). Pada dasarnya, menurut ketentuan Pasal 1 angka 10 Undang-undang No. 2 Tahun 2004 menyatakan: "perundingan bipartit adalah perundingan antara pekerja/buruh atau serikat pekerja/buruh dengan pengusaha untuk menyelesaikan Perselisihan Hubungan Industrial".

Kemudian, ketentuan Pasal 3 ayat (1) Undang-unang No. 2 Tahun 2004 mengatur secara substansial bahwa: "Perselisihan Hubungan Industrial wajib diupayakan penyelesaiannya terlebih dahulu melalui perundingan bipartit secara musyawarah untuk mencapai mufakat".

Demikian halnya ketentuan Pasal 136 ayat (1) Undang-undang No. 13 Tahun 2003, juga mengatur bahwa: "penyelesaian Perselisihan Hubungan Industrial wajib dilaksanakan oleh pengusaha dan

\footnotetext{
${ }^{28}$ Supomo Suparman, Op. Cit, 4-5.
}

pekerja/buruh atau serukat pekerja/buruh secara musyawarah untuk mufakat".

Dari ketentuan tersebut pada gilirannya diperoleh pemahaman bahwa setiap Perselisihan Hubungan Industrial, apapun jenis Perselisihannya, wajib untuk terlebihi dahulu diupayakan penyelesaiaanya secara bipartit. Dengan pengungkapan kata lain, prosedur dan mekanisme penyelesaian Perselisihan Hubungan Industrial secara bipartit adalah bersifat imperatif. Sekiranya para pihak yang berselisih berkeinginan untuk menyelesaikan Perselisihannya dengan mekanisme lain, seperti halnya mediasi, konsiliasi, arbitrase, ataupun melalui PHI, mekanisme tersebut baru bisa ditempuh jika sebelumnya telah ditempuh cara penyelesaian secara bipartit. ${ }^{29}$

Untuk memberikan gambaran yang lebih jelas tentang hal tersebut, kiranya patut dicermati ketentuan Pasal 4 ayat (1) UU No. 2 Tahun 2004 yang redaksional selengkapnya berbunyi sebagai berikut: "dalam hal perundingan bipartite gagal sebagaimana dimaksud dalam Pasal 3 ayat (3), maka salah satu atau kedua belah pihak mencatatkan Perselisihannya kepada instansi yang bertanggung jawab di bidang ketenagakerjaan setempat dengan melampirkan bukti bahwa upaya-upaya penyelesaian melalui perundingan bipartit telah dilakukan". Lebih dari hal itu, ketentuan Pasal 4 ayat (2) menegaskan bahwa: "apabila bukti-bukti sebagaimana dimaksud dalam ayat (1) tidak dilampirkan, maka instansi yang bertanggung jawab di bidang ketenagakerjaan mengembalikan berkas untuk dilengkapi paling lambat dalam waktu 7 (tujuh) hari kerja terhitung sejak tanggal diterimanya pengembalian berkas".

Bahkan, apabila para pihak ingin menyelesaikan Perselisihan Hubungan Industrial di antara mereka melalui PHI, persyaratan untuk membuktikan bahwa penyelesaian Perselisihan pernah diupayakan secara bipartite merupakan hal yang tidak

${ }^{29}$ Mohammad Saleh, Lilik Mulyadi, Seraut Wajah Pengadilan Hubungan Industrial Indonesia, (Bandung: Citra Aditya Bakti, 2012), 59. 
dapat ditawar-tawar, ${ }^{30}$ seperti yang diatur dalam Pasal 83 ayat (1) UU No. 2 Tahun 2004 yang menggariskan: "pengajuan gugatan yang tidak dilampiri risalah penyelesaian melalui mediasi atau konsiliasi, maka hakim Pengadilan Hubungan Industrial wajib mengembalikan gugatan kepada penggugat".

Penyelesaian Perselisihan secara bipartite dimaksudkan untuk mencari jalan keluar atas Perselisihan Hubungan Industrial dengan cara musyawarah untuk mencapai kata mufakat secara internal, dalam arti kata tidak melibatkan pihak lain, di luar pihakpihak yang berselisih. Penyelesaian Perselisihan secara bipartite ini harus diselesaikan paling lama 30 hari kerja sejak tanggal dimulainya perundingan. Apabila dalam jangka waktu 30 hari salah satu pihak menolak untuk berunding atau telah dilakukan perundingan, tetapi tidak mencapai kesepakatan, perundingan bipartite dianggap gagal. ${ }^{31}$

Dalam hal perundingan bipartit gagal, salah satu atau kedua belah pihak mencatatkan Perselisihannya kepada instansi yang bertanggung jawab di bidang ketenagakerjaan setempat dengan melampirkan bahwa upaya-upaya penyelesaian melalui perundingan bipartite telah dilakukan. Apabila bukti-bukti tersebut tidak dilampirkan, instansi yang bertanggung jawab di bidang ketenagakerjaan mengembalikan berkas untuk untuk dilengkapai paling lambat 7 ( Tujuh ) hari kerja terhitung sejak tanggal diterimanya pengembalian berkas. ${ }^{32}$

Apabila perundingan bipartite tersebut dapat mencapai kesepakatan penyelesaian, dibuat perjanjian bersama yang ditandatangani oleh para pihak dan mengikat dan menjadi hukum serta wajib dilaksanakan oleh para pihak.Perjanjian bersama tersebut wajib didaftarkan oleh para pihak yang melakukan perjanjian dalam Pengadilan

\footnotetext{
${ }^{30}$ Ibid, 60.

${ }^{31} \mathrm{lbid}$.

32 Ibid, 61
}

Hubungan Industrial pada pengadilan negeri di wilayah para pihak mengadakan perjanjian bersama.Perjanjian bersama yang telah didaftarkan diberikan akta bukti pendaftaran perjanjian bersama dan merupakan bagian yang tidak terpisahkan dari perjanjian bersama.Apabila perjanjian bersama tidak dilaksanakan oleh satu pihak, pihak yang dirugikan dapat mengajukan permohonan eksekusi kepada PHI pada pengadilan negeri di wilayah perjanjian bersama didaftar untuk mendapat penetapan eksekusi. ${ }^{33}$

\section{Penyelesaian melalui Mediasi}

Lingkup penyelesaian perselisihan hubungan industrial melalui mediasi meliputi keempat jenis perselisihan, yakni perselisihan hak, perselisihan keentingan, perselisihan PHK, dan perselisihan antara serikat pekerja/ serikat buruh dalam satu perusahaan (Pasal 1 angka 11 UndangUndang Nomor 2 tahun 2004).

Berdasarkan ketentuan Undang-Undang Nomor 2 tahun 2004 mekanisme penyelesaian perselisihan hubungan industrial melalui mediasi diatur sebagai berikut :

a. Penyelesaian perselisihan melalui mediasi dilakukan oleh mediator yang berada disetiap kantor instansi yang bertanggung jawab dibidang ketenagakerjaan kabupaten/kota.

b. Selambat-lambatnya 7 hari kerja setelah menerima pelimpahan penyelesaian perselisihan, mediator harus mengadakan penelitian tentang duduknya perkara dan segera mengadakan sidang mediasi.

c. Apabila tercapai kesepakatan melalui mediasi, dibuat perjanjian bersama yang ditandatangani oleh para pihak dan disaksikan oleh mediator serta didaftar dipengadilan hubungan industrial untuk mendapatkan akta bukti pendaftaran.

d. Apabila tidak tercapai kesepakatan melalui mediasi maka, maka :

\footnotetext{
${ }^{33}$ Ibid, 62.
} 
- Mediator mengeluarkan anjuran tertulis

- Anjuran tertulis harus sudah disampaikan kepada para pihak selambat-lambatnya 10 hari kerja sejak sidang mediasi pertama.

- Para pihak harus sudah memberikan jawaban secara tertulis kepada mediator selambat-lambatnya 10 hari kerja sejak menerima anjuran tertulis, yang isinya menyetujui atau menolak anjuran.

- Para pihak yang tidak memberikan pendapatnya (atau tidak memberika jawaban) dianggap menolak anjuran tertulis.

- Apabila para pihak menyetujui anjuran tertulis, mediator harus sudah selesai membantu para pihak membuat perjanjian bersama selambat-lambatnya 3 hari kerja sejak anjuran tertulis disetujui yang kemudian didaftar dipengadilan hubungan industrial untuk mendapatkan akta bukti pendaftaran.

e. Mediator menyelesaikan tugas mediasi selambat-lambatnya 30 hari kerja sejak pelimpahan perkara. $^{34}$

\section{Penyelesaian melalui Konsiliasi}

Lingkup penyelesaian perselisihan hubungan industrial melalui konsiliasi meliputi tiga jenis perselisihan, yakni perselisihan kepentingan, perselisihan pemutusan hubungan kerja (PHK), dan perselisihan antar serikat pekerja/serikat buruh dalam satu perusahaan (pasal 1 angka 13 Undang-Undang Nomor 2 tahun 2004). Penyelesaian perselisihan hubungan industrial melalui konsiliasi ditengahi oleh seorang atau lebih konsiliator yang netral.

\section{Penyelesaian melalui Arbitrase}

Arbitrase adalah penyelesaian suatu perselisihan kepentingan, dan perselisihan antar serikat pekerja/serikat buruh hanya dalam satu perusahaan, di luar pengadilan

\footnotetext{
${ }^{34}$ Abdul Khakim, Op. Cit, 153-154.
}

hubungan industrial melalui kesepakatan tertulis dari para pihak yang berselisih untuk menyerahkan penyelesaian perselisihan kepada arbiter yang putusannya mengikat para pihak da besifat final.

\section{Pengadilan Hubungan Industrial}

Dalam hal tidak tercapai penyelesaian melalui konsiliasi atau mediasi, salah satu pihak atau para pihak dapat mengajukan gugatan kepada pengadilan hubungan industrial. Pengadilan Hubungan Industrial merupakan pengadilan khusus yang berada dalam lingkungan peradilan umum, yang bertugas dan berwenang untuk memeriksa dan memutus:

a. Ditingkat pertama mengenai Perselisihan hak dan Perselisihan pemutusan hubungan kerja;

b. Ditingkat pertama dan terakhir mengenai perselishan kepentingan dan Perselisihan antar serikat pekerja/serikat buruh dalam satu perusahaan. ${ }^{35}$

\section{Serikat Pekerja/ Serikat Buruh}

Pekerja/buruh sebagai Warga Negara mempunyai persamaan kedudukan dalam hukum, kepentingan untuk mendapatkan pekerjaan dan penghidupan yang layak, berkepentingan atas kebebasan berserikat, mengeluarkan pendapat, berkumpul dalam satu organisasi, serta mendirikan dan menjadi anggota serikat pekerja/serikat buruh.

Hak menjadi anggota serikat pekerja/serikat buruh merupakan hak asasi pekerja/buruh yang telah dijamin di dalam Pasal 28 Undang-undang Dasar 1945. Untuk mewujudkan hak tersebut, kepada setiap pekerja/buruh harus diberikan kesempatan yang seluas-luasnya mendirikan dan menjadi anggota serikat pekerja/buruh. Serikat pekerja/serikat buruh berfungsi sebagai sarana untuk memperjuangkan, melindungi, dan membela hak dan melakukan pembelaan

${ }^{35}$ Zaeni Asyhadie II, Hukum Kerja Hukum Ketenagakerjaan Bidang Hubungan Kerja, (Jakarta: Raja Grafindo Persada, 2007), 78. 
kepentingan pekerja/buruh dan keluarganya. Dalam menggunakan hak tersebut, pekerja/buruh dituntut bertanggung jawab untuk menjamin kepentingan yang lebih luas yaitu kepentingan bangsa dan negara. Oleh karena itu, penggunaan kepentingan tersebut dilaksanakan dalam kerangka hubungan industrial yang harmonis, dinamis, dan berkeadilan.

Hak berserikat bagi pekerja/buruh, sebagaimana diatur dalam Konvensi Internasional Labour Organization (ILO) Nomor 87 tentang Kebebasan Berserikat dan Perlindungan hak untuk Berorganisasi, dan Konvensi ILO Nomor 98 mengenai berlakunya Dasar-dasar daripada hak untuk Berorganisasi dan untuk Berunding Bersama sudah diratifikasi oleh Indonesia menjadi bagian dari peraturan perundang-undangan nasional.

Kemerdekaan berserikat dan berkumpul serta menyampaikan pendapat merupakan hak dasar yang dimiliki oleh Warga negara dari suatu negara hukum demokratis yang berkedaulatan rakyat. Hak-hak yang dimiliki manusia berdasarkan martabatnya sebagai manusia dan bukan karena pemberian masyarakat atau negara disebut hak asasi manusia. $^{36}$

Serikat Pekerja/buruh merupakan mitra kerja pengusaha yang sangat penting dalam proses produksi, sebagai wakil pekerja dalam rangka melakukan pembelaan hak pekerja/ buruh dan keluarganya, menjamin kelangsungan perusahaan. Sehubungan dengan hal itu, serikat pekerja/ serikat buruh merupakan sarana untuk memperjuangkan hak-hak pekerja/ buruh dan menciptakan hubungan industrial yang harmonis, dinamis, dan berkeadilan. Oleh karena itu, pekerja/ buruh dan serikat pekerja/ serikat buruh harus memiliki rasa tanggung jawab atas kelangsungan perusahaan dan sebaliknya pengusaha harus memperlakukan pekerja/ buruh sebagai mitra sesuai dengan harkat dan martabat kemanusiaan.

\footnotetext{
${ }^{36}$ Frans Magnis Suseno, Etika Politik, Prinsip-prinsip Moral Dasar Modern, (Jakarta: Gramedia Pustaka Utama, 1999), 73.
}

Kenyataan yang ada dalam proses berlangsungnya suatu hubungan industrial tidak seperti yang diharapkan. Majikan sering menempatkan buruh pada posisi yang rendah, sebagai faktor ekstern yang kurang diperhatikan. Untuk itulah diperlukan adanya suatu wadah bagi buruh sebagai upaya mensejajarkan posisi buruh dan majikan dalam proses hubungan industrial dalam suatu serikat pekerja/buruh. ${ }^{37}$

Serikat pekerja/serikat buruh didirikan secara bebas, terbuka, mandiri, demokratis, dan bertanggung jawab oleh pekerja/buruh untuk memperjuangkan hak dan kepentingan serta meningkatkan kesejahteraan pekerja/buruh dan keluarganya.

\section{Pengertian Serikat Pekerja}

Pekerja adalah setiap penduduk dalam usia kerja yang melakukan kegiatan ekonomis, baik dalam hubungan kerja di perusahaan maupun di luar hubungan kerja seperti pekerja mandiri, pekerja keluarga dan pekerja di sektor informal lainnya.

Pengertian Serikat Pekerja/Serikat Buruh menurut Pasal 1 ayat (1) UndangUndang No. 21 Tahun 2000 tentang Serikat Pekerja adalah organisasi yang dibentuk dari, oleh, dan untuk pekerja/buruh baik di perusahaan maupun di luar perusahaan, yang bersifat bebas, terbuka, mandiri, demokratis, dan bertanggung jawab guna memperjuangkan, membela serta melindungi hak dan kepentingan pekerja/buruh serta meningkatkan kesejahteraan pekerja/buruh dan keluarganya.

Serikat pekerja harus demokratis, artinya serikat pekerja harus memiliki konstitusi yang disetujui oleh sebagian besar anggotanya. Konstitusi itu berupa dokumen tertulis yang mencakup aturan-aturan mengenai:

a. Bagaimana pemimpin serikat pekerja dipilih dan bagaimana prosedur untuk menangani pemilihan pemimpin dan perhitungan suara.

${ }^{37}$ Asri Wijayanti, Hukum Ketenagakerjaan Pasca Reformasi, (Jakarta: Sinar Grafika, 2015), 91. 
b. Tujuan dan fungsi serikat pekerja, serta bidang dan ruang lingkup industry yang diorganisir oleh serikat pekerja

c. Iuran keanggotaan serikat pekerja, berapa besar jumlahnya dan bagaimana pembayarannya.

\section{Dasar Pembentukan Serikat Pekerja}

Serikat pekerja dibentuk berdasarkan:

a. Undang-undang Dasar Negara RI Tahun 1945

b. Piagam PBB tentang Hak-hak asasi manusia Pasal 20 ayat (1) dan Pasal 23 ayat (4)

c. Undang-undang No. 18 Tahun 1956 tentang Ratifikasi Konvensi ILO No. 98 mengenai hak berorganisasi dan berunding bersama

d. Kepres No. 23 Tahun 1998 tentang pengesahan Konvensi ILO No. 87 tentang kebebasan berserikat dan perlindungan hak berorganisasi

e. Kepmenaker No. PER-201/MEN/1999 tentang pendaftaran serikat pekerja

f. Kepmenaker No. PER-16/MEN/2000 tentang tata cara pendaftaran serikat pekerja

g. UU No. 21 Tahun 2000 tentang Serikat Pekerja

h. UU No. 13 Tahun 2003 tentang Ketenagakerjaan

i. UU No. 2 Tahun 2004 tentang Penyelesaian Perselisihan Hubungan Kerja

j. AD/ART serikat pekerja yang bersangkutan.

\section{Pembentukan Serikat Pekerja}

Kemerdekaan berserikat, berkumpul, mengeluarkan pikiran baik secara lisan maupun secara tulisan, memperoleh pekerjaan dan penghidupan yang layak bagi kemanusiaan, serta mempunyai kedudukan yang sama dalam hukum merupakan hak setiap Warga Negara termasuk pekerja. Dengan kata lain, pekerja sebagai Warga Negara mempunyai persamaan kedudukan dalam hukum, hak untuk mendapatkan pekerjaan dan penghidupan yang layak, mengeluarkan pendapat, berkumpul dalam satu organisasi, serta mendirikan dan menjadi anggota serikat pekerja. ${ }^{38}$

Pembentukan serikat pekerja sangat penting bukan hanya sekedar mengakomodasikan hak dasar pekerja untuk berorganisai, akan tetapi juga sebagai salah satu pemeran utama dalam penciptaan dan pelaksanaan hubungan industrial. ${ }^{39}$

UU Nomor 21 Tahun 2000 menganut multi union sistem yaitu memberikan kebebasan kepada pekerja/buruh untuk membentuk serikat pekerja/serikat buruh. Setiap 10 (sepuluh) orang pekerja/buruh menurut undang - undang tersebut telah dapat membentuk suatu serikat pekerja/serikat buruh. Ketentuan ini memungkinkan dalam satu perusahaan bisa berdiri beberapa serikat pekerja. Banyaknya serikat pekerja/serikat buruh dalam satu perusahaan dapat memungkinkan terjadinya Perselisihan antar serikat pekerja yang biasanya menyangkut masalah keanggotaan yang akan berdampak pada posisi mayoritas sebuah serikat pekerja/serikat buruh di perusahaan tersebut. ${ }^{40}$

Sebagaimana diatur pada pasal 5 ayat (1) dan ayat (2) Undang-undang nomor 21 tahun 2000 tentang Serikat Pekerja yakni : setiap pekerja/buruh berhak membentuk dan menjadi anggota serikat pekerja/serikat buruh dan serikat pekerja/serikat buruh dibentuk oleh sekurang-kurangnya 10 (sepuluh) orang pekerja/buruh.

Pembentukan serikat pekerja/serikat buruh ini dengan ketentuan sebagai berikut :

a. Setiap serikat pekerja/serikat buruh harus memiliki anggaran dasar dan anggaran rumah tangga dimana sekurang-kurangnya memuat ( Pasal 11 ayat 1 dan ayat 2 Undang-undang Nomor 21 Tahun 2000 tentang Serikat Pekerja) :

1) Nama dan lambang

2) Dasar negara, asas, dan tujuan

\footnotetext{
38 Ibid, 33.

$39 \mathrm{lbid}, 35$.

40 Maimun, Hukum Ketenagakerjaan Suatu Pengantar, (Jakarta: Pradnya Paramita, 2007), 29.
} 
3) Tanggal pendirian

4) Tempat kedudukan

5) Keanggotaan dan kepengurusan

6) Sumber dan pertanggung jawaban keuangan

7) Ketentuan perubahan AD/ART

b. Memberitahukan secara tertulis kepada instansi pemerintah yang bertanggungjawab di bidang ketenagakerjaan setempat untuk dicatat dengan dilampiri :

1) Daftar nama anggota pembentuk;

2) Anggaran dasar dan anggaran rumah tangga;

3) Susunan dan nama pengurus (Pasal 18 UU No.21/2000).

c. Instansi pemerintah yang bertanggungjawab, selambat-lambatnya 21 (dua puluh satu) hari kerja, terhitung sejak tanggal diterima pemberitahuan, wajib mencatat dan memberikan nomor bukti pencatatan terhadap serikat pekerja yang telah memenuhi ketentuan (Pasal 20 ayat 1 UU No.21 Tahun 2000); buku pencatatan harus dapat dilihat setiap saat dan terbuka untuk umum.

d. Dalam hal serikat pekerja belum memenuhi ketentuan, maka instansi pemerintah yang bertanggung jawab itu dapat menangguhkan pencatatan dan pemberian nomor bukti pencatatan dengan memberitahukan secara tertulis kepada serikat pekerja selambatlambatnya 14 (empat belas) hari kerja, terhitung sejak tanggal diterima pemberitahuan (Pasal 20 ayat 2 dan 3 UU No.21 Tahun 2000).

e. Pengurus serikat pekerja yang telah mempunyai nomor bukti pencatatan, harus memberitahukan secara tertulis keberadaannya kepada mitra kerjanya sesuai dengan tingkatannya ${ }^{41}$ (Pasal 23 UU No.21 Tahun 2000).

\section{Tujuan dan Fungsi Serikat Pekerja}

a. Tujuan Serikat Pekerja

${ }^{41}$ Hardijan Rusli, Hukum Ketenagakerjaan 2003 (Jakarta: Ghalia Indonesia, 2004), 153-154.
Sesuai dengan Undang-undang No. 21 Tahun 2000 tentang Serikat pekerja/ serikat buruh Pasal 4 ayat (1), bahwa serikat pekerja bertujuan memberikan perlindungan, pembelaan hak dan kepentingan, bagi pekerja dan keluarganya.

b. Fungsi Serikat Pekerja

Sebagai sarana penyalur aspirasi dalam memperjuangkan hak dan kepentingan pekerja, sebagai lembaga perunding mewakili pekerja, melakukan perlindungan dan pembelan terhadap hak-hak dan kepentingan pekerja, sebagai wadah pembinaan dan wahana peningkatan pengetahuan pekerja, sebagai wahana peningkatan kesejahteraan pekerja dan keluarganya dan sebagai wakil untuk dan atas nama anggota baik di dalam maupun di luar pengadilan.

\section{Hak dan Kewajiban Serikat Pekerja}

Serikat pekerja yang telah mempunyai nomor bukti pencatatan berhak :

a. Membuat Perjanjian Kerja Bersama dengan pengusaha;

b. Mewakili pekerja dalam menyelesaikan Perselisihan industrial;

c. Mewakili pekerja dalam lembaga ketenagakerjaan;

d. Membentuk lembaga atau melakukan kegiatan yang berkaitan dengan usaha peningkatan kesejahteraan pekerja antara lain dengan mendirikan koperasi, yayasan, dan lain-lain.

Serikat pekerja yang telah mempunyai nomor bukti pencatatan berkewajiban :

a. Melindungi dan membela anggota dari pelanggaran hak-hak dan memperjuangkan kepentingannya;

b. Memperjuangkan peningkatan kesejahteraan anggota dan keluarganya;

c. Mempertanggung jawabkan kegiatan organisasi kepada anggotanya sesuai dengan anggaran dasar dan anggaran rumah tangga. 


\section{Perlindungan Terhadap Serikat Pekerja}

Siapapun dilarang untuk menghalanghalangi atau memaksa pekerja untuk membentuk atau tidak membentuk, menjadi pengurus atau tidak menjadi pengurus, menjadi anggota atau tidak menjadi anggota dan/ atau menjalankan atau tidak menjalankan kegiatan serikat pekerja dengan cara:

a. Melakukan pemutusan hubungan kerja, memberhentikan sementara, menurunkan jabatan, atau melakukan mutasi;

b. Tidak membayar atau mengurangi upah pekerja/buruh;

c. Melakukan intimidasi dalam bentuk apapun;

d. Melakukan kampanye anti pembentukan serikat pekerja/serikat buruh;

Sanksi bagi pengusaha yang mengabaikan isi pasal 28 Undang-Undang Nomor 21 Tahun 2000 tentang Serikat pekerja /serikat buruh akan di ganjar berupa sanksi atau denda seperti dalam Pasal 43 Undang-undang Nomor 21 Tahun 2000 tentang serikat pekerja/serikat buruh, yaitu: "Barang siapa yang menghalang-halangi atau memaksa pekerja/buruh sebagaimana dimaksud Pasal 28, dikenakan sanksi pidana penjara paling singkat 1 (satu) Tahun dan paling lama 5 (lima) tahun

\section{PERANAN SERIKAT PEKERJA DI PERUSAHAAN PT. DASA WINDU AGUNG DALAM MEMPERJUANGKAN PERSELISIHAN PHK TERHADAP PEKERJA DENGAN STATUS PEKERJA KONTRAK (PKWT)}

Serikat Pekerja di PT. Dasa Windu Agung

PT. Dasa Windu Agung adalah sebuah perusahaan berbadan hukum yang beralamat di Jalan Pangkalan 1A Nomor 18 Bantar Gebang Kota Bekasi. Perusahaan PT. Dasa Windu Agung berdiri sejak tahun 1990 yang memproduksi perlengkapan acessoris automotif yakni Head Lining (Plafon bagian dalam mobil), press forming (peredam mesin), Emblem (logo/merk mobil). Tepatnya pada bulan Agustus tahun 2018, telah berdiri di PT. Dasa Windu Agung Gabungan Serikat Pekerja Manufaktur Independen Indonesia (GSPMII) PT. Dasa Windu Agung yang telah tercatat di Dinas Tenaga Kerja Kota Bekasi.

Menurut Henry Simamora Serikat Pekerja adalah sebuah organisasi yang berunding bagi karyawan tentang upah-upah, jam-jam kerja, dan syarat-syarat dan kondisikondisi pekerjaan lainnya ${ }^{42}$

Latar belakang berdirinya serikat pekerja/ serikat buruh di PT. Dasa Windu Agung adalah karena adanya kepedulian antar sesama pekerja pada saat itu. Atas dasar kesadaran dan perlu adanya payung hukum terhadap pekerja di PT. Dasa Windu Agung, maka pekerja di PT. Dasa Windu Agung sepakat untuk mendirikan serikat pekerja dan bergabung dengan serikat pekerja dengan nama Gabungan Serikat Pekerja Manufaktur Independen Indonesia (GSPMII) Kabupaten/Kota Bekasi.

\section{Perselisihan Pekerja Dengan Perusahaan Terkait Pemutusan Hubungan Kerja Pekerja Kontrak (PKWT)}

Hubungan kerja merupakan suatu hubungan hukum yang dilakukan oleh minimal dua subjek hukum yaitu pengusaha dan pekerja. Hal tersebut menunjukkan kedudukan para pihak pengusaha dan pekerja yang didalamnya terdapat hak dan kewajiban dari masing-masing pihak. Hubungan kerja lahir karena adanya perjanjian kerja. Perjanjian melahirkan perikatan, perikatan yang lahir karena perjanjian inilah yang merupakan hubungan kerja. ${ }^{43}$

Dalam pelaksanaan hubungan kerja sangat rentan terjadi adanya perselisihan antara pihak pengusaha dan pihak pekerja, karena perbedaan hak dan kepentingan diantara keduanya. Seperti halnya yang

\footnotetext{
42 Henry Simamora, Manajemen Sumber Daya Manusia, (Yogyakarta: STIE YKPN, 1999), 78.

${ }^{43}$ Abdul Rachmad Budiono, Hukum Perburuhan di Indonesia, (Jakarta: Raja Grafindo Persada, 1995), 25.
} 
terjadi di perusahaan PT. Dasa Windu Agung telah terjadi Perselisihan Hubungan Industrial mengenai Pemutusan Hubungan Kerja terhadap pekerja dengan status PKWT / Kontrak.

Sehubungan dengan akibat yang ditimbulkan dengan adanya pemutusan hubungan kerja khususnya bagi buruh dan keluarganya Imam Soepomo berpendapat bahwa, pemutusan hubungan kerja bagi buruh merupakan permulaan dari segala pengakhiran, permulaan dari berakhirnya mempunyai pekerjaan, permulaan dari berakhirnya kemampuan membiayai keperluan hidup sehari-hari keluarganya, permulaan dari berakhirnya kemampuan menyekolahkan anak-anak dan sebagainya. ${ }^{44}$

Perselisihan Hubungan Industrial sebagaimana yang terjadi diperusahaan PT. Dasa Windu Agung berawal dari tindakan pengusaha yang telah melakukan pemutusan hubungan kerja secara sepihak dengan alasan habis kontrak. Hal ini ditolak oleh pihak pekerja karena pihak pekerja menganggap bahwa pengusaha dalam melakukan pemutusan hubungan kerja (PHK) dan dalam melaksakan perjanjian kerja tidak sesuai dengan ketentuan dan peraturan perundangundangan. Bahwa pihak pekerja berkeyakinan hubungan kerjanya adalah hubungan perjanjian kerja waktu tidak tertentu (PKWTT / Tetap). Akibat dari perjanjian kerja yang tidak sesuai dengan ketentuan yang diatur dalam UndangUndang Ketenagakerjaan terkait sifat pekerjaan yang ada di Perusahaan PT. Dasa Windu Agung yakni pekerjaan yang bersifat tetap dan terus menerus. hal ini dikarenakan dari mulai perusahaan berdiri sejak tahun 1990 sampai dengan saat ini tahun 2020 masih melakukan kegiatan usaha yang sama, yaitu bergerak dalam bidang pembuatan aksesoris dan suku cadang kendaraan bermotor / Automotif.

Serikat Pekerja GSPMII di PT. Dasa Windu Agung selaku kuasa pekerja dan atas nama serta mewakili anggota berusaha

\footnotetext{
${ }^{44}$ Imam Soepomo, Op. Cit, 124.
}

melakukan perundingan terhadap pimpinan perusahaan PT. Dasa Windu Agung mengenai permasalahan Pemutusan Hubungan Kerja secara sepihak yang dilakukan kepada pekerja Muhamad Sulur, Yayan Mulyana, Anggi, Ade Repai, dan Tatang daryanto untuk dikembalikan kepada posisi jabatan semula dan memberikan kembali hak-haknya. Upaya ini terus dilakukan oleh Serikat Pekerja PT. Dasa Windu Agung demi tercapainya kesepakatan atau penyelesaian masalah.

Dalam upaya menyelesaikan permasalahan tersebut Serikat Pekerja GSPMII PT. Dasa Windu Agung lebih mengambil langkah dialog ataupun diplomasi daripada mengambil langkah mogok kerja walaupun langkah tersebut diperbolehkan oleh undang-undang dengan catatan sesuai dengan prosedur yang disyaratkan oleh undang-undang ketenagakerjaan yaitu UU Nomor. 13 tahun 2003.

\section{Upaya Serikat Pekerja dalam memperjuangkan hak-hak pekerja sesuai dengan peranan dan fungsi Serikat Pekerja.}

Dalam melaksanakan hubungan industrial, pemerintah mempunyai fungsi menetapkan kebijakan, memberikan pelayanan, melaksanakan pengawasan, dan melakukan penindakan terhadap pelanggaran peraturan ketenagakerjaan. $^{45}$

perundang-undangan

Sesuai dengan peran dan fungsi serikat pekerja, maka serikat pekerja GSPMII di PT. Dasa Windu Agung telah berupaya melakukan pembelaan terhadap anggotanya. Salah satu bentuk pembelaan terhadap anggotanya yaitu dengan berupaya menyelesaikan permasalahan dengan cara meminta pembatalan surat keputusan PT. Dasa Windu Agung yang telah melakukan pemutusan hubungan kerja (PHK) terhadap pekerja yang bernama Muhamad sulur,

\footnotetext{
${ }^{45}$ Marjan Miharja, Pengantar Hukum Indonesia, (Jakarta: CV
} Qiara Media, 2019), 114 
Yayan Mulyana, Anggi, Ade Repai, dan Tatang daryanto.

Penyelesaian perselisihan hubungan industrial wajib dilaksanakan oleh pengusaha dan pekerja/ buruh atau serikat pekerja/ serikat buruh secara musyawarah untuk mufakat. Dalam hal penyelesaian secara musyawarah untuk mufakat tidak tercapai, maka pengusaha dan pekerja/ buruh atau serikat pekerja/ serikat buruh menyelesaikan perselisihan hubungan industrial melalui prosedur penyelesaian perselisihan hubungan yang diatur dengan undang-undang. ${ }^{46}$

Perbedaan pendapat antara pekerja yang diwakili Serikat Pekerja GSPMII PT. Dasa Windu Agung selaku kuasa pekerja dengan pihak perusahaan PT. Dasa Windu Agung mengenai permintaan pembatalan surat Pemutusan Hubungan Kerja (PHK) merupakan salah satu bentuk Perselisihan Hubungan Industrial sebagaimana yang diatur dalam undang-undang Nomor 2 tahun 2004 Pasal 1 angka 1, bahwa Perselisihan Hubungan Industrial adalah perbedaan pendapat yang mengakibatkan pertentangan antara pengusaha atau gabungan pengusaha dengan pekerja/buruh atau serikat pekerja/serikat buruh karena adanya Perselisihan mengenai hak, Perselisihan kepentingan, Perselisihan pemutusan hubungan kerja, dan Perselisihan antar serikat pekerja/serikat buruh dalam satu perusahaan.

Pemutusan hubungan kerja antara pekerja dan pengusaha tidak boleh dilakukan secara sewenang-wenang, Melainkan ada hal-hal tertentu yang harus dipenuhi oleh kedua belah pihak supaya PHK itu tidak mencederai rasa keadilan diantara kedua belah pihak. $^{47}$

Serikat pekerja GSPMII PT. Dasa Windu Agung selaku kuasa pekerja dalam mengupayakan penyelesaian permasalahan tentang Pemutusan Hubungan Kerja secara sepihak yang dilakukan oleh Perusahaan terhadap pekerja Muhamad Sulur, Yayan

\footnotetext{
${ }^{46} \mathrm{Ibid}, 115$

${ }^{47}$ Prints Darwan, Hukum Ketenagakerjaan Indonesia, (PT. Citra Aditya: Bandung, 2000), 132.
}

Mulyana, Anggi, Ade Repai, dan Tatang daryanto menempuh jalur penyelesaian sesuai dengan ketentuan Undang-Undang Nomor 2 tahun 2004 tentang Penyelesaian Perselisihan Hubungan Industrial antara lain

\section{Melakukan Perundingan Bipartit}

Menurut Undang-Undang Nomor 4 tahun 2004 tentang Penyelesaian Perselisihan Hubungan Industrial Pasal (1) angka 10 yang dimaksud dengan Perundingan Bipartit adalah perundingan antara pekerja/ buruh atau serikat pekerja/serikat buruh dengan pengusaha untuk menyelesaikan perselisihan hubungan industrial. Dalam hal ini serikat pekerja PT. Dasa Windu Agung mengajukan Permohonan Perundingan Bipartit pertama yang diajukan kepada pihak perusahaan pada tanggal 12 Juli 2018, tetapi tidak tercapai kesepakatan, kemudian mengajukan kembali Permohonan Perundingan Bipartit yang ke dua pada tanggal 20 Juli 2018, tetapi masih saja tidak tercapai kesepakatan. Karena upaya penyelesaian melalui Perundingan Bipartit telah dilakukan namun tetap saja tidak menemukan titik temu penyelesaian atau kata sepakat, maka Serikat Pekerja GSPMII PT. Dasa Windu Agung mengajukan upaya penyelesaian berikutnya yakni mengajukan Surat Permohonan Mediasi kepada Kantor Kepala Dinas Tenagakerja Kota Bekasi.

\section{Melakukan Permohonan Mediasi}

Mediasi sebagai salah satu parnata penyelesaian sengketa bisnis mulai dikenal di Indonesia sejak tahun 1990- an, Mediasi mempunyai karakteristik yang khas, yaitu mempunyai jalan kompromi dengan melibatkan pihak ketiga yang disebut Mediator. $^{48}$ Sesuai Pasal (1) angka 11 Undang-Undang Nomor 4 tahun 2004 tentang Penyelesaian Perselisihan Hubungan Industrial yang dimaksud dengan Mediasi Hubungan Industrial yang selanjutnya

48 Bambang Heri Supriyanto, Mediasi Sebagai Salah Satu Penyelesaian Sengketa Bisnis di Pusat Mediasi Nasional. Jurnal Reformasi Hukum, Vol XIV No. 1 JanuariJuni 2010, Jakarta : Universitas Islam Jakarta. 
disebut mediasi adalah penyelesaian perselisihan hak, perselisihan kepentingan, perselisihan pemutusan hubungan kerja, dan perselisihan antar serikat pekerja/serikat buruh hanya dalam satu perusahaan melalui musyawarah yang ditengahi oleh seorang atau lebih mediator yang netral.

Pada tanggal 3 Agustus 2018 pihak serikat pekerja mengajukan permohonan Mediasi di Kantor Dinas Tenaga Kerja Kota Bekasi. Pihak Mediator telah melakukan pemanggilan terhadap para pihak untuk menghadiri setiap jadwal Sidang Mediasi. Pihak Mediator dalam melaksanakan tugas dan fungsinya berupaya mendamaikan para pihak yang berselisih dengan telah melakukan panggilan sidang sebanyak dua kali namun dan juga mencoba memberikan win-win solusi terhadap kedua belah pihak yang berperkara. Namun upaya penyelesaian pada sidang Mediasi di Kantor Dinas Tenaga Kerja Kota Bekasi tetap saja tidak tercapai penyelesaian, sehingga pegawai Mediator Dinas Tenaga Kerja Kota Bekasi mengeluarkan surat anjuran nomor 567/1396-Disnaker.Hijamsostek tanggal 16 Oktober 2018 dan surat anjuran nomor 567/1446-Disnaker.Hijamsostek tanggal 25 Oktober 2018.

Terhadap isi surat anjuran dari pegawai Mediator Dinas tenaga kerja Kota Bekasi, Serikat Pekerja GSPMII PT. Dasa Windu Agung memberikan jawaban dengan menyatakan menerima isi surat anjuran tersebut, akan tetapi pihak perusahaan PT. Dasa Windu Agung menolak isi surat anjuran tersebut.

Selanjutnya Pegawai Mediator Dinas tenaga kerja Kota Bekasi mengeluarkan Risalah Penyelesaian Perselisihan hubungan Industrial terhadap Muhamad Sulur Dkk (3 orang) pada tanggal 27 November 2018 dan Risalah Penyelesaian Perselisihan hubungan Industrial terhadap Ade Repai dan Tatang Daryanto pada tanggal 27 November 2018, sebagai persyaratan untuk mengajukan gugatan ke Pengadilan Hubungan Industrial pada Pengadilan Negeri kelas 1A Bandung sesuai dengan ketentuan UU No. 2 Tahun 2004

\section{Mengajukan Gugatan ke Pengadilan Hubungan Industrial}

Pengadilan Hubungan Industrial merupakan pengadilan khusus yang berada dalam lingkungan peradilan umumn yang bertugas dan berwenang untuk memeriksa dan memutus di tingkat pertama mengenai Perselisihan hak dan Perselisihan Pemutusan Hubungan Kerja, di tingkat pertama dan terakhir mengenai Perselishan Kepentingan dan Perselisihan Antar Serikat Pekerja/Serikat Buruh dalam satu perusahaan. $^{49}$

Setelah upaya penyelesaian perselisihan mengenai Pemutusan Hubungan Kerja sepihak oleh perusahaan PT. Dasa Windu Agung terhadap pekerja Muhamad sulur, Yayan Mulyana, Anggi, Ade Repai, dan Tatang daryanto yang dilakukan melalui perundingan bipartit dan mediasi gagal, selanjutnya Serikat Pekerja GSPMII PT. Dasa Windu Agung menempuh jalur melalui gugatan pengadilan.

Yang dimaksud dengan jalur melalui gugatan pengadilan yaitu Pengadilan Hubungan Industrial sebagaimana dimaksud dalam Undang-undang Nomor 2 Tahun 2004 tentang Penyelesaian Perselisihan Hubungan Industrial, yang merupakan pengadilan khusus yang berada pada lingkungan peradilan umum (Pengadilan Negeri), yang berwenang memeriksa, mengadili, dan putusan

\section{Hasil Penelitian dan Pembahasan}

Isi Putusan No. 47/Pdt.Sus-PHI/2019/PN.Bdg

Negara Republik Indonesia sebagai negara hukum menganut sistem hukum "civil law" (Eropa Kontinental), yang diwarisi dari pemerintah kolonial Belanda semenjak ratusan tahun yang lalu. Dalam sistem civil law, hukum tertulis merupakan primadona sebagai sumber hukum. Dengan sistem ini mempengaruhi berpikir corak

${ }^{49}$ Zaeni Asyhadie II, Op. Cit, 80. 
hakim di Indonesia dalam memeriksa dan memutus perkara. ${ }^{50}$

Prinsip utama dari sistem ini yaitu "hukum memperoleh kekuatan hukum mengikat, karena diwujudkan dalam peraturan yang berbentuk undang-undang dan tersusun secara sistematis didalam kodifikasi atau kompilasi tertentu. ${ }^{51}$

Yang menjadi sumber hukum dalam sistem ini adalah undang-undang yang dibentuk oleh pemegang kekuasaan legislative. Selain itu ada juga peraturanperaturan yang dibuat oleh pemegang kekuasaan eksekutif sesuai wewenang yang ditentukan oleh undang-undang. ${ }^{52}$

Sebagai contoh Putusan Hakim dalam perkara PT. Dasa Windu agung yang telah melakukan Pemutusan Hubungan Kerja sepihak terhadap pekerja yang bernama Muhamad sulur, Yayan Mulyana, Anggi, Ade Repai, dan Tatang daryanto dengan alasan habis kontrak. Hal ini ditolak oleh pihak pekerja karena pihak pekerja merasa dan berkeyakinan hubungan kerjanya merupakan hubungan perjanjian kerja waktu tidak tertentu (PKWTT/ Tetap) akibat dari perjanjian kerja yang tidak sesuai ketentuan yang diatur didalam Undang-Undang Ketenagakerjaan. Bahwa sifat pekerjaan yang selama ini dilakukan diperusahaan PT. Dasa Windu Agung adalah bersifat tetap dan terus menerus, hal ini dikarenakan dari mulai perusahaan berdiri sejak tahun 1990 sampai dengan saat ini tahun 2020 PT. Dasa Windu Agung masih melakukan kegiatan usaha yang sama, yaitu beregrak dalam bidang pembuatan aksesoris dan suku cadang kendaraan bermotor / Automotif.

Selanjutnya terhadap perkara tersebut para pekerja mengadukan sekaligus menguasakan tentang permasalahanya kepada Pimpinan Unit Kerja (PUK-GSPMII) PT. Dasa Windu Agung untuk melakukan upaya penyelesaian perselisihan PHK

\footnotetext{
50 Josef M Monteiro, Putusan Hakim Dalam Penegakan Hukum di Indonesia, Jurnal Hukum Pro Justisia, April 2007, Volume 2 No. 2.

${ }^{51}$ Marjan Miharja, Pengantar IImu Hukum, (Jakarta: CV Qiara Media, 2019), 41

52 lbid.
}

tersebut. Pimpinan Unit Kerja (PUKGSPMII) PT. Dasa Windu Agung selaku yang diberi kuasa oleh pekerja telah melakukan upaya-upaya penyelesaian permasalahan sesuai dengan UndangUndang Nomor 2 tahun 2004 tentang tata cara penyelesaian Perselisihan Hubungan Industrial yang pertama yaitu melalui upaya perundingan Bipartit namun gagal, selanjutnya mengajukan permohonan Mediasi ke Dinas Tenaga Kerja Kota bekasi, upaya tersebut juga gagal sehingga Serikat Pekerja mengajukan upaya selanjutnya yaitu mengajukan Gugatan ke Pengadilan Hubungan Industrial. Setelah pengajuan Gugatan diterima dan diperoses dalam sidang, Hakim Pengadilan Hubungan Industrial memutuskan perkara tersebut dengan Putusan No. 47/Pdt.SusPHI/2019/PN.Bdg.

Putusan hakim PHI dakam perkara No. 47/Pdt.Sus-PHI/2019/PN.Bdg yang diputus dalam Permusyawaratan Majelis Hakim Pengadilan Hubungan Industrial pada Pengadilan Negeri Kelas IA Bandung, pada hari Senin tanggal 21 April 2019, oleh WASPIN SIMBOLON, SH., M.H., sebagai Ketua Majelis, ATMARI, S.H., MH., dan SRI WAHYUNI, S.H., sebagai Hakim anggota dan putusan tersebut diucapkan dalam sidang yang terbuka untuk umum, pada hari Jumat, tanggal 29 April 2019 oleh Ketua Majelis WASPIN SIMBOLON, SH., M.H., didampingi oleh hakim-hakim anggota dan di hadiri oleh Asep Peni Latipania, SH.Panitera Pengganti Pengadilan Hubungan Industrial pada Pengadilan Negeri Kelas I A Bandung dengan dihadiri oleh Kuasa Penggugat dan Kuasa tergugat.

\section{Tentang Duduknya Perkara}

Bahwa para penggugat (Muhamad Sulur, Yayan Mulyana, Anggi, Ade Repai, dan Tatang daryanto) dengan surat gugatannya yang didaftarkan di Kepaniteraan Pengadilan Hubungan Industrial pada Pengadilan Negeri Bandung Kelas IA Khusus pada tanggal 30 Januari 2019 dengan nomor registrasi : 47/Pdt.Sus- 
PHI/2019/PN Bdg telah mengajukan hal-hal sebagai berikut :

a. Bahwa PT. Dasa Windu Agung berdiri sejak tahun 1990 yang memproduksi perlengkapan acessoris automotif yakni Head Lining (plafond bagian dalam mobil), press forming (peredam mesin), Emblem (logo/merk mobil).

b. Bahwa hubungan kerja antara Muhamad Sulur, Yayan Mulyana, Anggi, Ade Repai, dan Tatang daryanto (penggugat) dengan Pihak Perusahaan PT. Dasa Windu Agung (tergugat) didasarkan pada Perjanjian Kerja Waktu Tertentu (PKWT) yang tidak memenuhi ketentuan dan persyaratan yang ditetapkan oleh peraturan perundang-undangan, karena Obyek pekerjaan dari Perjanjian Kerja Waktu Tertentu (PKWT) adalah Pekerjaan yang bersifat tetap dan masih berlangsung sampai saat ini.

c. Seharusnya perjanjian kerja waktu tertentu (PKWT) antara penggugat dengan para tergugat adalah batal demi hukum karena Perjanjian Kerja Waktu Tertentu (PKWT) yang dibuat antara penggugat dengan tergugat tidak memenuhi ketentuan dan persyaratan yang ditetapkan oleh peraturan perundang-undangan.

d. PKWT yang dilakukan oleh perusahaan PT. Dasa Windu Agung hanya untuk membatasi jangka waktu berlakunya suatu perjanjian pada pekerjaan yang bersifat tetap dibagian Produksi, bagian Press Forming Headling, dan bagian Maitenance. Perpanjangan atau pembaharuan Perjanjian Kerja Waktu Tertentu (PKWT) yang dilakukan oleh Tergugat juga tidak dicantumkan mengenai pekerjaan mana yang dinyatakan belum selesai atau tidak menunjuk secara jelas pesanan/order mana yang belum selesai yang dikerjakan oleh para Penggugat di bagian Press Forming, Headlining, produksi, bagian maintenance.
Bahwa akibat hukum yang timbul dari Perjanjian Kerja Waktu Tertentu (PKWT) yang tidak sesuai dengan ketentuan hukum, maka Perjanjian Kerja Waktu Tertentu (PKWT) demi hukum berubah menjadi Perjanjian Kerja Waktu Tidak Tertentu (PKWTT), sesuai dengan ketentuan yang diatur dalam pasal 59 ayat (7) UU No. 13 Tahun 2003 tentang Ketenagakerjaan.

\section{Tentang Pertimbangan Hukum}

Mengenai isi pertimbangan hukumnya dalam Putusan No. 47/Pdt.SusPHI/2019/PN.Bdg diantaranya sebagai berikut Menimbang, bahwa dalam perkara a quo Majelis Hakim terlebih dahulu akan memeriksa dan mempertimbangkan secara seksama gugatan dan bukti -bukti yang telah diajukan Para Penggugat serta jawaban dan bukti -bukti yang telah diajukan Tergugat tentang status hubungan kerjanya yang pernah berlangsung antara Para Penggugat dengan Tergugat sebelum perkara a quo ini di perselisihkan apakah hubungan kerjanya didasarkan pada perjanjian kerja waktu tertentu (PKWT) atau yang didasarkan pada perjanjian kerja waktu tidak tertentu (PKWTT).

Menimbang, bahwa berdasarkan bukti P-1.3, T-6, T-13, T-28, T-24 berupa surat perjanjian kerja waktu tertentu, bukti T-5, T12 berupa surat pernyataan permohonan kerja kembali dan bukti P-1.4, T-19, T-4 berupa surat keterangan kerja serta bukti T-3, T-11, T-18 berupa surat kesepakatan akhir kontrak, berdasarkan bukti-bukti tersebut didapat fakta hukum bahwa Para Penggugat dengan Tergugat pernah berlangsung hubungan kerja dengan perjanjian kerja waktu tertentu (PKWT) sebagai berikut, Muhamad Sulur PKWT mulai tanggal 18 Maret 2013 dan berakhir tanggal 17 September 2015, PKWT mulai tanggal 15 Maret 2016 dan berakhir

tanggal 14 Maret 2017. Yayan Mulyana PKWT mulai tanggal 18 September 2012 dan berakhir tanggal 17 September 2015, PKWT mulai tanggal 15 Maret 2016 dan berakhir tanggal 14 Maret 2017. Anggi 
PKWT mulai tanggal 12 Mei 2017 dan berakhir tanggal 11 November 2017. Ade Repai PKWT mulai tanggal 12 Mei 2017 dan berakhir tanggal 11 Desember 2017. Tatang Daryanto PKWT mulai tanggal 23 Juni 2014 dan berakhir tanggal 22 Juni 2016.

Atas berakhirnya PKWT tersebut di atas, Para Penggugat dalam persidangan perkara a quo tidak ada bukti bahwa Para Penggugat tersebut memperselisihkan atas berakhirnya PKWT tersebut, oleh karenanya Majelis Hakim berpendapat bahwa antara Para Penggugat denganTergugat atas berakhir hubungan kerjanya

karena berakhirnya PKWTnya sebagaimana bukti P-1.3, T-6, T-13, T-28, T24, P-1.4, T-19, T-4 T-3, T-11, T-18, tidak ada perselisihan atas pelaksanaan dan berakhirnya PKWT tersebut.

Menimbang, bahwa selanjutnya dalam perkara aquo pada pokoknya Para Penggugat mendalilkan perselisihan pemutusan hubungan kerja antara Para Penggugat dengan Tergugat terjadi diakibatkan tindakan Tergugat melakukan pemutusan hubungan kerja terhadap Para Penggugat dengan alasan habis kontrak tanpa adanya penetapan dari lembaga penyelesaian perselisihan hubungan industrial, sedangkan Tergugat membantahnya yang mendalilkan pada pokoknya bahwa terputusnya hubungan kerja antara Tergugat dengan Para Penggugat karena berakhirnya jangka waktu Perjanjian Kerjanya.

Menimbang, bahwa setelah memeriksa bukti-bukti tertulis di persidangan berdasarkan bukti P-1.2, T-8, T-15, P-3.2, T29, P-4.2, T-25, T-21, berupa Perjanjian Kerja Waktu Tertentu, bukti T-7, T-14, T-20 berupa surat pernyataan permohonan kerja kembali dan bukti T-10, T-17, T-31, T-27, T23, berupa surat keterangan kerja, berdasarkan pada bukti - bukti tersebut didapat fakta hukum bahwa hubungan kerja yang telah berakhir adalah berlangsung dan diperjanjikan secara tertulis antara Para Penggugat dengan Tergugat pada perselisihan perkara a quo ini dalam perjanjian kerja waktu tertentu ( PKWT ) sebagai berikut, Muhamad Sulur 03-05-2017 02-05-2018 Bukti P-1.2, T-8, Yayan Mulyana 03-05-2017 02-05-2018 Bukti T15, Anggi 12-11-2017 11-05-2018 Bukti P3.2, T-29, Ade Repai 12-12-2017 11-062018 Bukti P-4.2, T-25, Tatang Daryanto 2607-2016 25-07-2018 Bukti T-21.

Menimbang, bahwa berdasarkan bukti T-1 berupa nota pemeriksaan dan bukti T-2 berupa bukti pencatatan PKWT, didapat fakta hukum bahwa Tergugat untuk memenuhi nota pemeriksaan Dinas Tenaga Kerja Dan Transmigrasi Balai Pelayanan Pengawasan Ketenagakerjaan Provinsi Jawa Barat nomor 560/326-BP2K.Wil.2 terkait isi nota pemeriksaan tersebut yang memerintahkan kepada Tergugat untuk mencatatkan PKWT pekerjanya ke Dinas Tenaga Kerja Kota Bekasi, dan terhadap PKWT Para Penggugat (vide : P-1.2, T-8, T15, P-3.2, T-29, P-4.2, T-25, T-21) tersebut telah dilakukan pencatatan oleh Tergugat ke Dinas Tenaga Kerja Kota Bekasi dengan pencatatan nomor : 560 / Reg.102 / PKWT /Disnaker.Hijamsostek tanggal 17 September 2018.

Menimbang, bahwa berdasarkan ketentuan dalam Pasal 1 angka 15 UndangUndang Nomor 13 tahun 2003 Tentang Ketenagakerjaan mengatur yaitu hubungan kerja adalah hubungan antara pengusaha dengan pekerja/buruh berdasarkan perjanjian kerja, yang mempunyai unsur pekerjaan, upah, dan perintah.

Menimbang, bahwa berdasarkan ketentuan dalam Pasal 50 Undang-Undang Nomor 13 tahun 2003 Tentang Ketenagakerjaan mengatur yaitu Hubungan kerja terjadi karena adanya perjanjian kerja antara pengusaha dan pekerja/buruh.

Menimbang, bahwa berdasarkan ketentuan dalam Pasal 1 angka 14 UndangUndang Nomor 13 tahun 2003 Tentang Ketenagakerjaan mengatur yaitu perjanjian kerja adalah perjanjian antara pekerja/buruh dengan pengusaha atau pemberi kerja yang memuat syarat syarat kerja, hak, dan kewajiban para pihak. 
Menimbang, bahwa berdasarkan ketentuan dalam Pasal 52 Undang-Undang Nomor 13 tahun 2003 Tentang Ketenagakerjaan mengatur yaitu,Perjanjian kerja dibuat atas dasar a. kesepakatan kedua belah pihak, b. kemampuan atau kecakapan melakukan perbuatan hukum, c. adanya pekerjaan yang diperjanjikan; dan d. pekerjaan yang diperjanjikan tidak bertentangan dengan ketertiban umum, kesusilaan, dan peraturan perundang undangan yang berlaku. Perjanjian kerja yang dibuat oleh para pihak yang bertentangan dengan ketentuan sebagaimana dimaksud dalam ayat (1) huruf a dan b dapat dibatalkan. Perjanjian kerja yang dibuat oleh para pihak yang bertentangan dengan ketentuan sebagaimana dimaksud dalam ayat (1) huruf c dan d batal demi hukum.

Menimbang, bahwa dalam PKWT ( vide : P-1.2, T-8, T-15, P-3.2, T-29, P-4.2, T-25, T-21 ) yang diperjanjikan oleh Tergugat dengan Para Penggugat sampai dengan berakhirnya PKWT tersebut yang tidak lebih 3 (tiga) tahun adalah telah sesuai dengan ketentuan dalam Undang-Undang Nomor 13 Tahun 2003 Tentang

Ketenagakerjaan pasal 59 ayat (1) “ perjanjian kerja untuk waktu tertentu hanya dapat dibuat untuk pekerjaan tertentu yang menurut jenis dan sifat atau kegiatan pekerjaannya akan selesai dalam waktu tertentu, yaitu : a. pekerjaan yang sekali selesai atau yang sementara sifatnya, b. pekerjaaan yang diperkirakan penyelesaiannya dalam waktu yang tidak terlalu lama dan paling lama 3 (tiga) tahun, dan juga telah memenuhi ketentuan Kepmenakertrans RI No Kep100/Men/VI/2004 Pasal 3 ayat (1) PKWT untuk pekerjaan yang sekali selesai atau sementara sifatnya adalah PKWT yang didasarkan atas selesainya pekerjaan tertentu, dan ayat (2) PKWT sebagaimana dimaksud dalam ayat (1) dibuat untuk paling lama 3 (tiga) tahun.

Menimbang, bahwa Perjanjian Kerja dapat dibatalkan jika perjanjian yang dibuat oleh para pihak tidak memenuhi ketentuan
Undang-Undang Nomor 13 Tahun 2003 Tentang Kenagakerjaan pada pasal 52 ayat (1) huruf a yaitu adanya "kesepakatan kedua belah pihak " dan huruf b. kemampuan atau kecakapan melakukan perbuatan perbuatan hukum" , sedangkan perjanjian kerja disebut batal demi hukum jika perjanjian yang dibuat oleh para pihak tidak memenuhi ketentuan Pasal 52 ayat (1) huruf c yaitu adanya pekerjaan yang diperjanjikan dan pada huruf d.yaitu pekerjaan yang diperjanjikan tidak bertentangan dengan ketertiban umum, kesusilaan, dan peraturan perundanganundangan yang berlaku.

Menimbang, bahwa azas umum tentang perjanjian sesuai ketentuan pasal 1320 KUHPerdata jo ketentuan pasal 52 UU Nomor 13 tahun 2003 tentang Ketenagakerjaan, bahwasannya terhadap PKWT Para Penggugat ( vide : bukti P-1.2, T-8, T-15, P-3.2, T-29, P-4.2, T-25, T-21) setelah Majelis Hakim memeriksa perjanjian tersebut didapatkan fakta hukum yaitu adanya kesepakatan antara Para Penggugat dengan Tergugat, adanya kecakapan dari Para Penggugat, adanya hal yang diperjanjikan tentang jangka waktu perjanjian kerja, jenis pekerjaan, upah dan sistem pembayarannya, berakhirnya perjanjian kerja dan yang diperjanjikan tidak bertentangan dengan ketentuan UndangUndang atau suatu causa yang halal yaitu dengan menyepakati suatu surat perjanjian kerja yang telah diatandatangani oleh para pihak dalam hal ini Para Penggugat dengan Tergugat.

Menimbang, bahwa selanjutnya berdasarkan Pasal 61 ayat (1) huruf b Undang-Undang Nomor 13 Tahun 2003 tentang Ketenagakerjaan mengatur bahwa Perjanjian Kerja berakhir apabila berakhirnya jangka waktu perjanjian kerja. Menimbang, bahwa dalam PKWT yang ditandatatangani oleh Para Penggugat dengan Tergugat telah menyepakati dalam pasal 1 ayat (1) tentang jangka waktu dimulai dan berakhirnya PKWT tersebut, sehingga berdasarkan Pasal 61 ayat (1) huruf b Undang-Undang Nomor 13 Tahun 2003 
Tentang Ketenagakerjaan dan ketentuan Pasal 1 ayat (1) pada PKWT antara Para Penggugat dengan Tergugat Majelis Hakim berpendapat bahwasannya hubungan kerja Para Penggugat dengan Tergugat tersebut telah berakhir oleh karena berakhirnya waktu yang diperjanjikan dalam PKWT yang telah dibuat dan disepakati serta ditandatangani oleh Para Penggugat dengan Tergugat (vide: bukti P-1.2, T-8, T-15, P-3.2, T-29, P-4.2, T25, T-21).

Menimbang, bahwa tentang ketentuan pasal 1320 KUHPerdata tidak dapat dipisahkan dengan ketentuan pasal 1338 KUHPerdata "semua perjanjian yang dibuat oleh kedua belah pihak merupakan undangundang bagi yang membuatnya", dan sesuai dengan pertimbangan Majelis Hakim diatas bahwa perjanjian Kerja Waktu Tertentu Para Penggugat sudah memenuhi ketentuan pasal 52 UU Nomor 13 tahun 2003 tentang Ketenagakerjaan jo pasal 1320 KUHPerdata jo pasal 1338 KUHPerdata, maka perjanjian kerja waktu Tertentu mengikat demi hukum dan berlaku sebagai undang-undang bagi para pihak yaitu Para Penggugat dengan Tergugat, dan oleh karena berlaku mengikat sebagai Undang-undang bagi kedua belah pihak konsekuensinya adalah para pihak harus mematuhi ketentuan-ketentuan yang yang ada pada perjanjian kerja waktu tertentu tersebut, sehingga sejak berakhirnya PKWT sebagaimana yang disepakati dalam pasal 1 ayat (1) PKWT antara Para Penggugat dengan Tergugat ( vide : bukti $\mathrm{P}$ 1.2, T-8, T-15, P-3.2, T-29, P-4.2, T-25, T21) dan berdasarkan ketentuan pasal 61 ayat (1) huruf $b$ Undang-Undang Nomor 13 Tahun 2003 Tentang Ketenagakerjaan, Maka Majelis Hakim berpendapat demi hukum hubungan kerja antara Para Penggugat dengan Tergugat tersebut telah berakhir oleh karena berakhirnya waktu yang diperjanjikan dalam PKWT sehingga tidak mempunyai hubungan kerja lagi sejak berakhirnya PKWT antara Para Penggugat dengan Tergugat (vide :bukti P-1.2, T-8, T-15, P-3.2, T-29, P-4.2, T-25, T-21), oleh karenanya terhadap petitum Para Penggugat pada angka
2 sampai dengan angka 6 sudah seharusnya ditolak.

Menimbang, bahwa Para Penggugat dalam petitum pada angka 7 yaitu agar memerintahkan dan mewajibkan Tergugat untuk membayar upah proses kepada Para Penggugat secara tunai dan sekaligus yang totalnya Rp. 126.977.616,- (seratus dua puluh enam juta sembilan ratus tujuh puluh tujuh ribu enam ratus enam belas rupiah ), Majelis Hakim berpendapat bahwa oleh karena pengakhiran hubungan kerja yang dilakukan oleh Tergugat terhadap Para Penggugat sah secara hukum karena demi hukum antara Para Penggugat dengan Tergugat sudah tidak mempunyai hubungan kerja lagi sejak berakhirnya PKWT antara Para Penggugat dengan Tergugat ( vide : bukti P-1.2, T-8, T-15, P-3.2, T-29, P-4.2, T25, T-21), maka sesuai dengan pasal 93 ayat (1) Undang-Undang Nomor 13 Tahun 2003 tentang Ketenagakerjaan "Upah tidak dibayar apabila pekerja/buruh tidak melakukan pekerjaan", maka dengan demikian terhadap petitum Para Penggugat pada angka 7 haruslah dinyatakan ditolak.

Menimbang, bahwa tuntutan Para Penggugat dalam petitum angka 8 agar mewajibkan Tergugat membayar dwangsom sebesar Rp. 100.000,- ( seratus ribu rupiah ) setiap harinya kepada Para Penggugat sejak putusan ini berkekuatan hukum, oleh karena seluruh tuntutan para Penggugat ditolak sebagaimana telah dipertimbangkan sebelumnya, maka tidak ada relevansinya tuntutan dwangsom ini untuk dapat dikabulkan, dengan demikian terhadap petitum Para Penggugat pada angka 8 juga harus ditolak.

Menimbang, bahwa berdasarkan keseluruhan pertimbangan hukum di atas oleh karena gugatan Para Penggugat tidak cukup beralasan dan tidak didukungcdengan bukti-bukti yang cukup sesuai dengan ketentuan hukum yang berlaku, maka Majelis Hakim berpendapat sudah sepatutnyalah gugatan Para Penggugat untuk dinyatakan ditolak seluruhnya. Menimbang, bahwa bukti surat-surat yang diajukan oleh 
Para Penggugat dan bukti surat-surat yang diajukan oleh Tergugat selain yang telah dipertimbangkan di atas dinyatakan dikesampingkan karena tidak relevan dengan substansi materi dalam pokok perkara a quo.

Menimbang, bahwa oleh karena gugatan Para Penggugat ditolak seluruhnya sementara nilai gugatan kurang dari Rp. 150.000.000,- (seratus lima puluh juta rupiah) maka berdasarkan ketentuan Pasal 58 Undang- Undang Nomor 2 Tahun 2004 Tentang Penyelesaian Perselisihan Hubungan Industrial biaya yang timbul dalam perkara ini dibebankan kepada Negara dan jumlah biaya perkara akan ditetapkan dalam amar putusan. Memperhatikan ketentuan yang diatur dalam HIR, UndangUndang Nomor 2 Tahun 2004 tentang Penyelesaian Perselisihan Hubungan Industrial dan Undang- Undang Nomor 13 Tahun 2003 tentang Ketenagakerjaan, serta peraturan lain yang bersangkutan. Mengadili dalam pokok perkara, menolak gugatan Para Penggugat untuk seluruhnyadan membebankan biaya perkara ini kepada Negara sejumlah Rp. 600.000,- (enam ratus ribu rupiah).

\section{Analisis Putusan No. 47/Pdt.Sus- PHI/2019/PN.Bdg}

Pengakhiran suatu persoalan yang telah diserahkan kepada pengadilan untuk menyelesaikannya selalu diakhiri dengan putusan, akan tetapi putusan dalam persidangan atau putusan hakim bukanlah satu-satunya bentuk untuk menyelesaikan perkara, karena selain dari keputusan hakim masih terdapat penetapan sebagai salah satu pengakhiran perkara, kecuali hakim memeriksa dan memutus di tingkat pertama dan terakhir mengenai Perselisihan Kepentingan dan Perselisihan antar serikat pekerja/ serikat buruh dalam satu perusahaan. ${ }^{53}$

Tujuan diadakannya suatu proses di muka pengadilan adalah untuk memperoleh

\footnotetext{
${ }^{53}$ Zaeni Asyhadie II, Op. Cit, 158
}

putusan hakim. ${ }^{54}$ Putusan hakim atau lazim disebut dengan istilah putusan pengadilan merupakan sesuatu yang sangat diinginkan atau dinanti-nantikan oleh pihak-pihak yang berperkara guna menyelesaikan sengketa diantara mereka dengan sebaik-baiknya. Sebab dengan putusan hakim tersebut pihakpihak yang bersengketa mengharapkan adanya kepastian hukum dan keadilan dalam perkara yang mereka hadapi. ${ }^{55}$

Hakim dalam mengadili suatu perkara harus mendasarkan pada ketentuan hukum yang berlaku baik secara formil maupun materiil, dan sesuai dengan rasa keadilan masyarakat. Oleh karena itu putusan hakim haruslah mencerminkan cita hukum secara utuh, yaitu keadilan, kepastian dan kemanfaatan. Dalam rangka menghasilkan putusan-putusan yang berkualitas, diperlukan hakim yang memiliki penguasaan ilmu hukum, teori hukum, dan filsafat hukum yang memadai, disamping menguasai peraturan perundang-undangan. Selain itu hakim harus pula mampu berperan dalam penemuan hukum dan penciptaan hukum.

Menurut Sudikno Mertokusumo Putusan hakim adalah suatu pernyataan oleh hakim sebagai pejabat negara yang diberi wewenang untuk itu, diucapkan di persidangan dan bertujuan untuk mengakhiri atau menyelesaikan suatu perkara atau sengketa antara para pihak. $^{56}$ Dalam memberikan putusan atau penetapannya harus disertai alasan-alasan putusan atau pertimbangan-pertimbangan yang menjadi dasar untuk mengadili. Ketentuan yang mengharuskan adanya pertimbangan pengadilan ditentukan dalam Pasal $195 \mathrm{RBg}$ yang dinyatakan: "Keputusan hakim harus memuat secara singkat tetapi jelas tentang apa yang dituntut serta jawabannya, begitu pula tentang dasar-dasar keputusan dan akhirnya putusan pengadilan negeri

\footnotetext{
${ }^{54}$ M.Nur Rasaid, Hukum Acara Perdata, cet. III, (Jakarta: Sinar Grafika Offset, 2003), 48.

${ }^{55}$ Moh. Taufik Makarao, Pokok-pokok Hukum Acara Perdata, cet. I, (Jakarta: PT. Rineka Cipta, 2004), 124.

55 Sudikno Mertokusumo, Hukum Acara Perdata Indonesia (Yogyakarta: Liberty, 2008), 210.

${ }_{56} \mathrm{~K}$. Wantjik Saleh, Hukum Acara Perdata RBG/HR, (Jakarta: Ghalia Indonesia, 2004), 41.
} 
mengenai gugatan pokoknya serta biaya dan mengenai para pihak mana yang hadir pada waktu putusan diucapkan". 57

Keharusan adanya alasan-alasan atau pertimbangan dalam suatu putusan merupakan sebagai bentuk tanggung jawab hakim dan juga agar putusan tersebut memiliki wibawa. Menurut pendapat Moh. Taufik Makarao menyatakan: "Alasan-alasan atau argumentasi itu dimaksudkan sebagai pertanggungjawaban hakim terhadap masyarakat sehingga mempunyai nilai objektif, karena adanya alasan-alasan itulah, maka putusan mempunyai wibawa dan bukan karena hakim tertentu yang menjatuhkannya".

Pertimbangan atau alasan-alasan dalam putusan hakim terdiri atas dua bagian yaitu pertimbangan tentang duduknya perkara dan pertimbangan tentang hukumnya. Mengenai peristiwa atau duduk perkaranya merupakan tugas dari pihak yang mengemukakan dan membuktikannya dalam persidangan dengan menghadirkan atau menyediakan alat bukti, sedangkan mengenai hukumnya merupakan tugas dari para hakim. Sudikno Mertokusumo berpendapat: "Dalam proses perdata terdapat pembagian tugas yang tetap antara pihak dan hakim, para pihak harus mengemukakan peristiwanya, sedangkan soal hukum adalah urusan hakim". 58

Dalam putusan apabila tidak dicantumkan alasan-alasan atau kurangnya pertimbangan hakim, maka putusan tersebut tidak mencerminkan rasa keadilan. Putusan yang tidak lengkap atau kurang cukup dipertimbangkan (onvoldoende gemotiveerd) merupakan alasan untuk kasasi dan harus dibatalkan. $^{59}$

Pemberian pertimbangan oleh hakim dalam putusannya didasarkan kepada pengetahuan hakim mengenai peristiwa atau fakta hukum perkara yang diajukan kepadanya, pengetahuan hakim ini didasarkan kepada hasil dari pemeriksaan

\footnotetext{
${ }^{57}$ Moh. Taufik Makarao, Op. Cit. 6.

${ }^{58}$ Sudikno Mertokusummo, Op. Cit, 221.

${ }^{59}$ Sudikno Mertokusummo, A Pitlo, Bab-bab tentang

Penemuan Hukum, (Bandung: Citra Aditya Bakti, 1993), 15.
}

pembuktian dan berdasarkan kepada alat-alat bukti yang diajukan oleh pihak-pihak yang berperkara. Berdasarkan hasil pembuktian, maka hakim akan menghubungkan peristiwa atau fakta hukum dengan peraturan perundang-undangan yang mengatur peristiwa yang dihadapi. Upaya menghubungkan peristiwa tersebut dilakukan oleh hakim dengan mencari dalam peraturan hukum tertulis. Pencarian aturan yang mengatur permasalahan yang akan diputusnya merupakan upaya hakim dalam menerapkan aturan tertulis kepada peristiwa konkrit yang dihadapi, hal ini merupakan upaya penemuan hukum yang dilakukan oleh hakim. Upaya penemuan hukum merupakan suatu proses pembentukan hukum oleh hakim atau petugas-petugas hukum lainnya yang diberi tugas melaksanakan hukum terhadap peristiwa-peristiwa hukum konkrit. $^{60}$

Penemuan hukum yang dilakukan oleh hakim dalam pencarian peraturan yang diutamakan pada hukum tertulis. Apabila terdapat dalam ketentuan hukum tertulis, maka hakim tinggal menerapkan kepada perkara yang diperiksa dan diadilinya, sedangkan terhadap peristiwa atau fakta perkara yang ditanganinya tidak terdapat pengaturannya didalam ketentuan peraturan perundang-undangan, maka hakim dapat melakukan pencarian dalam rangka upaya penemuan hukum pada peraturan tidak tertulis yaitu peraturan yang hidup dan tumbuh didalam masyarakat. Diperbolehkannya hakim melakukan pencarian pada peraturan tidak tertulis untuk diterapkan kepada peristiwa konkrit yang dihadapinya dapat dilihat dalam ketentuan Pasal 25 ayat (1) Undang-undang No. 4 Tahun 2004 tentang Kekuasaan Kehakiman yang dinyatakan: "Segala putusan pengadilan selain harus memuat alasan dan dasar putusan tersebut, memuat pula pasal tertentu dari peraturan perundang-undangan yang bersangkutan atau sumber hukum tak

${ }^{60} \mathrm{lbid}, 17$. 
tertulis yang dijadikan dasar untuk mengadili".

Ketentuan Pasal 28 ayat (1) Undangundang No. 4 Tahun 2004 Tentang Kekuasaan Kehakiman tidak hanya memperbolehkan hakim menemukan hukum pada peraturan tertulis juga mewajibkan kepada hakim untuk menemukan hukum pada peraturan tidak tertulis sepanjang tidak terdapat peraturan tertulis yang mengatur perkara yang harus diselesaikannya, agar setiap putusan yang dikeluarkannya mencerminkan rasa keadilan dalam masyarakat.

Putusan No.

47/Pdt.SusPHI/2019/PN.Bdg yang telah diputus oleh Majelis Hakim Pengadilan Hubungan Industrial pada Pengadilan Negeri Kelas 1A Bandung, pada hari Senin tanggal 22 April 2019, dengan putusannya menyatakan gugatan penggugat di tolak untuk seluruhnya dan gugatan yang diajukan oleh pekerja tidak dapat dikabulkan dengan pertimbangan hukumnya. Menurut penulis, putusan tersebut bertentangan dengan ketentuan Undang-Undang nomor 13 tahun 2003 tentang Ketenagakerjaan Pasal 59 ayat (1), (2), dan (7). Selain itu Hakim PHI dalam memutus perkara tidak mencerminkan rasa keadilan dan cenderung mengabaikan buktibukti yang diajukan oleh penggugat (pihak pekerja).

\section{Kesimpulan}

1. Sesuai dengan ketentuan UndangUndang Nomor 2 tahun 2004 tentang Penyelesaian Perselisihan Hubungan Industrial Pasal 6 jo pasa 8 jo pasal 81 , peranan serikat pekerja di PT. Dasa Windu Agung dalam memperjuangkan pekerja PKWT/Kontrak yaitu dengan melakukan upaya Bipartit antara serikat pekerja dengan pengusaha. Karena upaya Bipartit gagal langkah selanjutnya adalah dengan mengajukan Mediasi ke Kantor Dinas Tenaga Keja. Upaya mediasipun ternyata masih gagal, maka upaya selanjutnya dengan mengajukan Gugatan Perselisihan PHK di Pengadilan Hubungan Industrial meskipun tidak berhasil.

2. Penerapan Perjanjian Kerja Waktu Tertentu (PKWT) di PT. Dasa Windu Agung tidak sesuai dengan ketentuan Undang-Undang nomor 13 tahun 2003 tentang Ketenagakerjaan Pasal 59 ayat (1), (2), dan (7). Selain itu Putusan Hakim PHI Bandung No. 47/Pdt.SusPHI/2019/PN.Bdg tidak mencerminkan rasa keadilan seperti yang tertuang dalam amar putusan didalam Pokok Perkara "Menolak gugatan penggugat untuk seluruhnya", dan hakim pengadilan mengabaikan dan mengenyampingkan bukti-bukti penggugat yang diajukan dalam gugatannya.

\section{E. Daftar Pustaka}

Abdul Khakim, Dasar-Dasar Hukum Ketenagakerjaan Indonesia Cetakan ke-4 Edisi Revisi, Bandung: PT. Citra Aditya Bakti, 2014.

Abdul Rachmad Budiono, Hukum Perburuhan di Indonesia, Jakarta: Raja Grafindo Persada, 1995.

Agusmidah, Hukum Ketenagakerjaan Indonesia Dinamika dan Kajian Teori, Jakarta: Ghalia Indonesia, 2010.

Aloewie,Tjepi F. Naskah Akademis Tentang Pemutusan Hubungan Kerja dan Penyelesaian Perselisihan Industrial, Jakarta: BPHN, 1996.

Amirudin dan Zainal Asikin, Pengantar Metode Penelitian Hukum, Jakarta: Rajawali Pers, 2010.

Asyhadie II Zaeni, Hukum Kerja Hukum Ketenagakerjaan Bidang Hubungan Kerja, Jakarta: Raja Grafindo Persada, 2007.

Bambang Heri Supriyanto, Mediasi Sebagai Salah Satu Penyelesaian Sengketa Bisnis di Pusat Mediasi Nasional. Jurnal Reformasi Hukum, Vol XIV No. 1 Januari-Juni 2010, Jakarta : Universitas Islam Jakarta. 
Djumadi, Hukum Perburuhan Perjanjian Kerja, Jakarta, Rajawali Pers, 2002.

Efendi Jonaedi dan Johny Ibrahim, Metode Penelitian Hukum Normatif dan Empiris, Depok: Prenada Media Group, 2018.

Henry Simamora, Manajemen Sumber Daya Manusia, Yogyakarta: STIE YKPN, 1999.

Husni Lalu, Pengantar Hukum Ketenagakerjaan Edisi Revisi, Jakarta: PT. Raja Grafindo Persada, 2015.

Judiantoro Hartono, Segi Hukum Penyelesaian Perselisihan Perburuhan, Jakarta: Rajawali Pers, 1992.

Kartasapoetra, G dkk, Hukum Perburuhan di Indonesia Berlandaskan Pancasila, Jakarta: Sinar Grafika, 1994.

Keputusan Menteri Tenaga Kerja Nomor 100 Tahun 2004 Tentang Pelaksanaan Perjanjian Kerja Waktu Tertentu.

Khakim Abdul, Pengantar Hukum Ketenagakerjaan Indonesia Berdasarkan Undang-Undang Nomor 13 Tahun 2003, Bandung: Citra Adytia Bhakti, 2003.

Maimun, Hukum Ketenagakerjaan Suatu Pengantar, Jakarta: Pradnya Paramita, 2007.

Marjan Miharja, Pengantar Hukum Indonesia, (Jakarta: CV Qiara Media, 2019.

Marjan Miharja, Pengantar Ilmu Hukum, Jakarta: CV Qiara Media, 2019.

Marjan Miharja, Ketenagakerjaan Dalam Institusi Organisasi Masyarakat (Ormas) Muhammadiyah Kramat jati, Jurnal Anadara Pengabdian Kepada Masyarakat. 2020, Vol.2 No.1.

Mertokusummo Sudikno, A Pitlo, Bab-bab tentang Penemuan Hukum, Bandung: Citra Aditya Bakti, 1993.
Mertokusumo Sudikno, Hukum Acara Perdata Indonesia, Yogyakarta: Liberty, 2008.

Prints Darwan, Hukum Ketenagakerjaan Indonesia, PT. Citra Aditya: Bandung, 2000.

Rasaid M.Nur, Hukum Acara Perdata, cet. III, Jakarta: Sinar Grafika Offset, 2003.

Rusli Hardijan, Hukum Ketenagakerjaan 2003, Jakarta: Ghalia Indonesia, 2004.

Saleh K. Wantjik, Hukum Acara Perdata $R B G / H R$, Jakarta: Ghalia Indonesia, 2004.

Saleh Mohammad, Lilik Mulyadi, Seraut Wajah Pengadilan Hubungan Industrial Indonesia, Bandung: Citra Aditya Bakti, 2012.

Soekanto Soerjono, Sri Mamudji, Penelitian Hukum Normatif, Jakarta: Raja Grafindo, 2013.

Soepomo Imam, Pengantar Hukum Perburuhan, Jakarta: Djambatan 1985.

Suparman Supomo, Hukum Acara Peradilan Hubungan Industrial, Tata cara penyelesaian Sengketa Perburuhan, Jakarta: Jala Aksara Permata, 2009.

Suseno Frans Magnis, Etika Politik, Prinsipprinsip Moral Dasar Modern, Jakarta: Gramedia Pustaka Utama, 1999.

Ugo \& Pujiyo, Hukum Acara Penyelesaian Perselisihan Hubungan Industrial, Jakarta: Sinar Grafika, 2012.

Undang-Undang Nomor 13 tahun 2003 Tentang Ketenagakerjaan.

Undang-Undang Nomor 2 tahun 2004 Tentang Penyelesaian Perselisihan Hubungan Industrial.

Undang-Undang Nomor 21 tahun 2000 Tentang Serikat Pekerja/ Serikat Buruh.

Wijayanti Asri, Hukum Ketenagakerjaan Pasca Reformasi Cetakan Ke 5, Jakarta: Sinar Grafika, 2015. 